University of Nebraska - Lincoln

DigitalCommons@University of Nebraska - Lincoln

Faculty Publications from the Harold W. Manter Laboratory of Parasitology

$12-1951$

\title{
Notes on the Nunamiut Eskimo and Mammals of the Anaktuvuk Pass Region, Brooks Range, Alaska
}

Robert L. Rausch

University of Washington, rausch@uw.edu

Follow this and additional works at: https://digitalcommons.unl.edu/parasitologyfacpubs

Part of the Parasitology Commons

Rausch, Robert L., "Notes on the Nunamiut Eskimo and Mammals of the Anaktuvuk Pass Region, Brooks Range, Alaska" (1951). Faculty Publications from the Harold W. Manter Laboratory of Parasitology. 502. https://digitalcommons.unl.edu/parasitologyfacpubs/502

This Article is brought to you for free and open access by the Parasitology, Harold W. Manter Laboratory of at DigitalCommons@University of Nebraska - Lincoln. It has been accepted for inclusion in Faculty Publications from the Harold W. Manter Laboratory of Parasitology by an authorized administrator of DigitalCommons@University of Nebraska - Lincoln. 
Rausch in ARCTIC (December 1951) 4(3). Copyright 1951, Arctic Institute of North America. Used by permission.

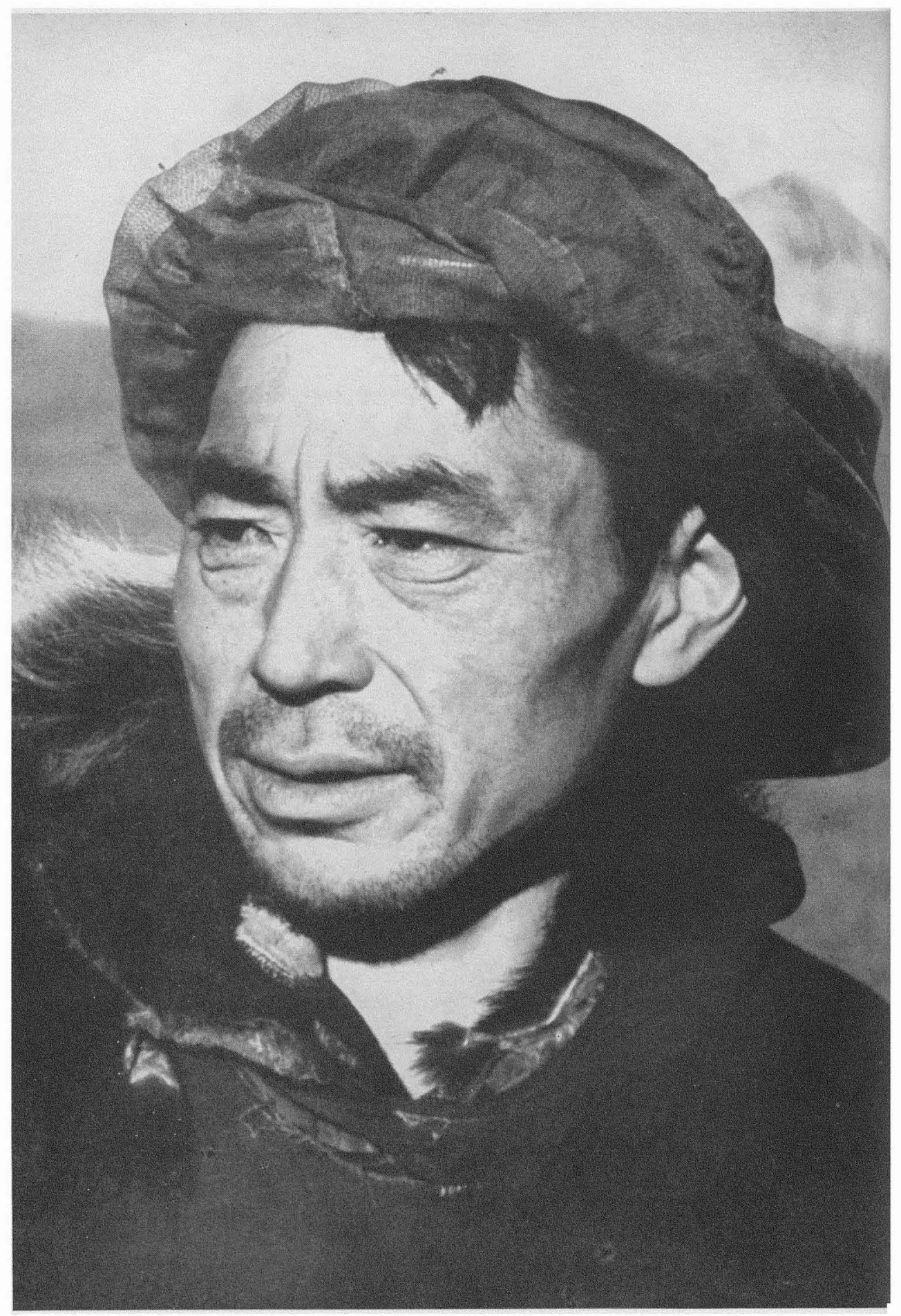

Fig. 1. Paneak, a Nunamiut man. 


\section{NO'TES ON THE NUNAMIUT ESKIMO AND MAMMALS OF THE ANAKTUVUK PASS REGION, BROOKS RANGE, ALASKA}

\section{Robert Rausch*}

$T$ HE Brooks Range, in northern Alaska, is biologically one of the least-known regions in North America. It has been during the last few years only that the use of light aircraft has made effective travel here possible. Since April 1949, I have made field observations in the Anaktuvuk Pass country, in the central part of the range; this work, the investigation of animal-borne disease, has necessitated a thorough study of the indigenous mammals. It is the purpose of this paper to record information of a biological nature on these mammals, with special emphasis on their relationship to the local Eskimo, the last remnant of the once numerous Nunamiut. ${ }^{1}$

The work has been carried out over a period of nearly three years and has of necessity been intermittent. I have made observations in all months except November and December, which are unfavourable for field work because of poor light conditions and lessened biological activity. Individual field trips have varied in length from ten days to nearly two months, and, in all, more than six months have been spent in this region. Several months have also been spent nearer the Arctic Coast, from Wainwright to Lake Schrader, where comparative observations have been made. In addition, Mr. F. L. Schiller, of the Arctic Health Research Center, and others, have contributed field observations.

After the first trips, because of transportation and supply problems, no camp was established and I lived among the Eskimo as one of them. This saved time by permitting more effective travel, but was particularly valuable in allowing greater insight into the lives of the people and an opportunity to learn something of their language.

Nunamiut words ${ }^{2}$ have been included in this paper whenever it was thought appropriate. The difficulties in writing Fskimo words phonetically are well recognized. However, through considerable personal effort towards learning the Nunamiut dialect, and with the aid of an educated, bilingual Eskimo living with this group, it is believed that a high degree of accuracy has been achieved.

The work in the Brooks Range has been greatly facilitated by the generous cooperation of specialists in other fields of biology, by persons concerned with

*Arctic Health Research Center, U.S. Public Health Service, Anchorage, Alaska.

${ }^{1}$ Nunamiut ("people of the land") in this paper refers specifically to the Inland Eskimo formerly living from the Killik River to the Anaktuvuk River, but now existing as a small semi-nomadic group in the region of Analituvuk Pass.

${ }^{2}$ All Eskimo words have been written phonetically, except that certain sounds represented by the letter $g$, which do not occur in European languages, are not indicated, and $\mathrm{ch}$ following $a$ or $o$, and the letter $i$ represent the same sounds as in the German language. 
148 THE NUNAMIUT FSKMIO AND MAMMALS OF THE ANAKTUVUK PASS REGION

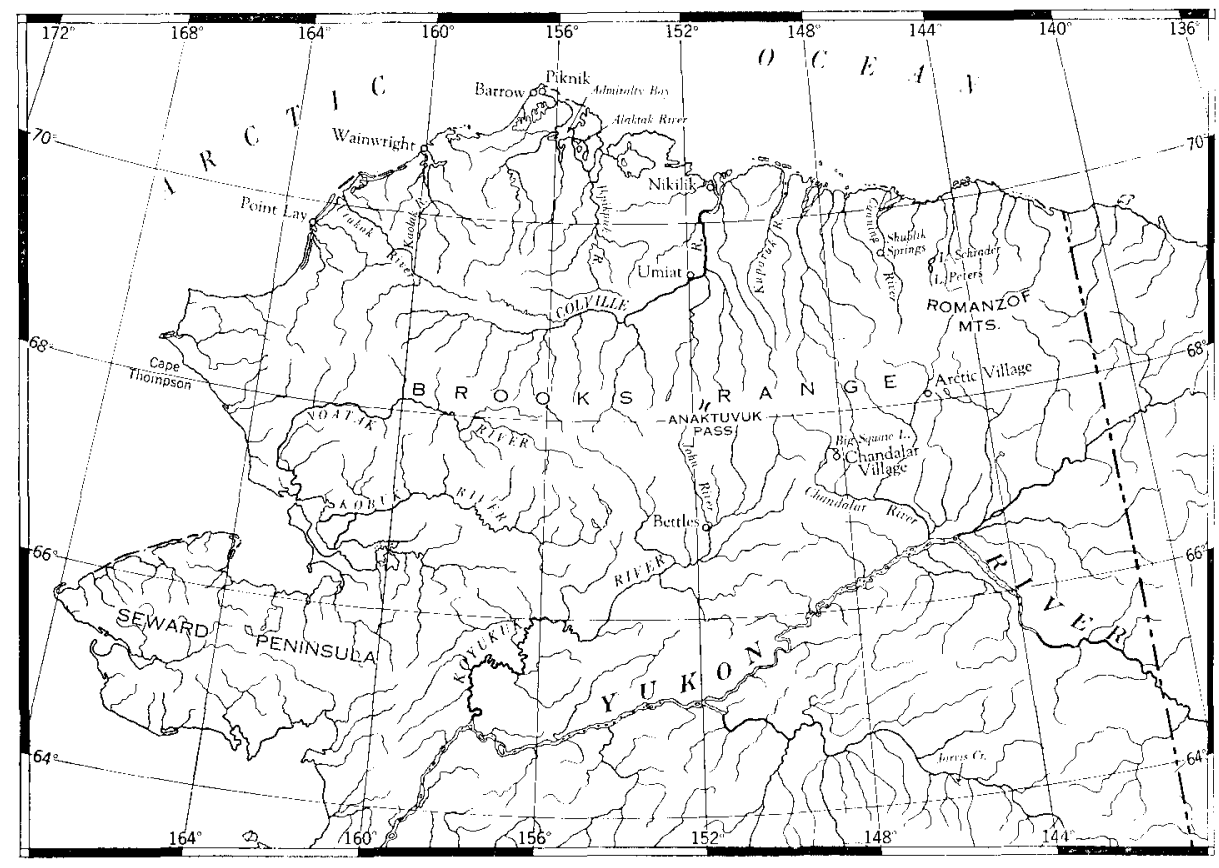

Fig. 2. Northern Alaska.

transportation and other necessary details, and, most important, by the Fskimo themselves. This opportunity is taken to express appreciation of this aid:-

Dr. Laurence Irving, former Scientific Director of the Arctic Research Laboratory at Point Barrow, with whom I first entered this region, deserves particular thanks. Professor George MacGinitie, who succeeded Dr. Irving at Point Barrow. contributed much to further the field work, and his efforts are much appreciated. The personnel of Naval Petroleum Reserve No. 4, at Point Barrow, and the Arctic Contractors, at Fairbanks, were very cooperative in arranging for transportation and supplies.

Mr. Thomas Brower and Mr. Clay Kaigilak, of Barrow Village, accompanied me on certain trips and their companionship contributed much to the enjoyment of the field work. Mr. Brower's intimate knowledge of arctic biology, especially of the local birds, was very helpful.

I was fortunate to spend a few weeks in the Brooks Range with Mr. Lloyd Spetzman, of the University of Minnesota, who has spent several ficld seasons studying the botany of the Arctic Slope and of the Brooks Rangc. His aid with plant identifications contributed much to my learning something of the botany of the region. Dr. George Llano, formerly of the Smithsonian Institution, identified the lichens, and Dr. William Stecre, of Stanford University, identified the mosses.

The staff of the Division of Mamnals, U.S. National Museum, made available every facility during two sessions of study there. Appreciation is expressed to Dr. Remington Kellogg, Dr. David H. Johnson, and Dr. Henry Setzer for valuable suggestions and generous cooperation. Thanks are also due to the U.S. Fish and Wildlife Service personnel at the National Museum, who permitted the use of the Biological Survey collections. Dr. R. M. Anderson, of the Canadian National Museum, allowed the comparison of the skulls of Brooks Range grizzlies with those collected by him farther east, and made helpful comments as to the relationships of these bears. 


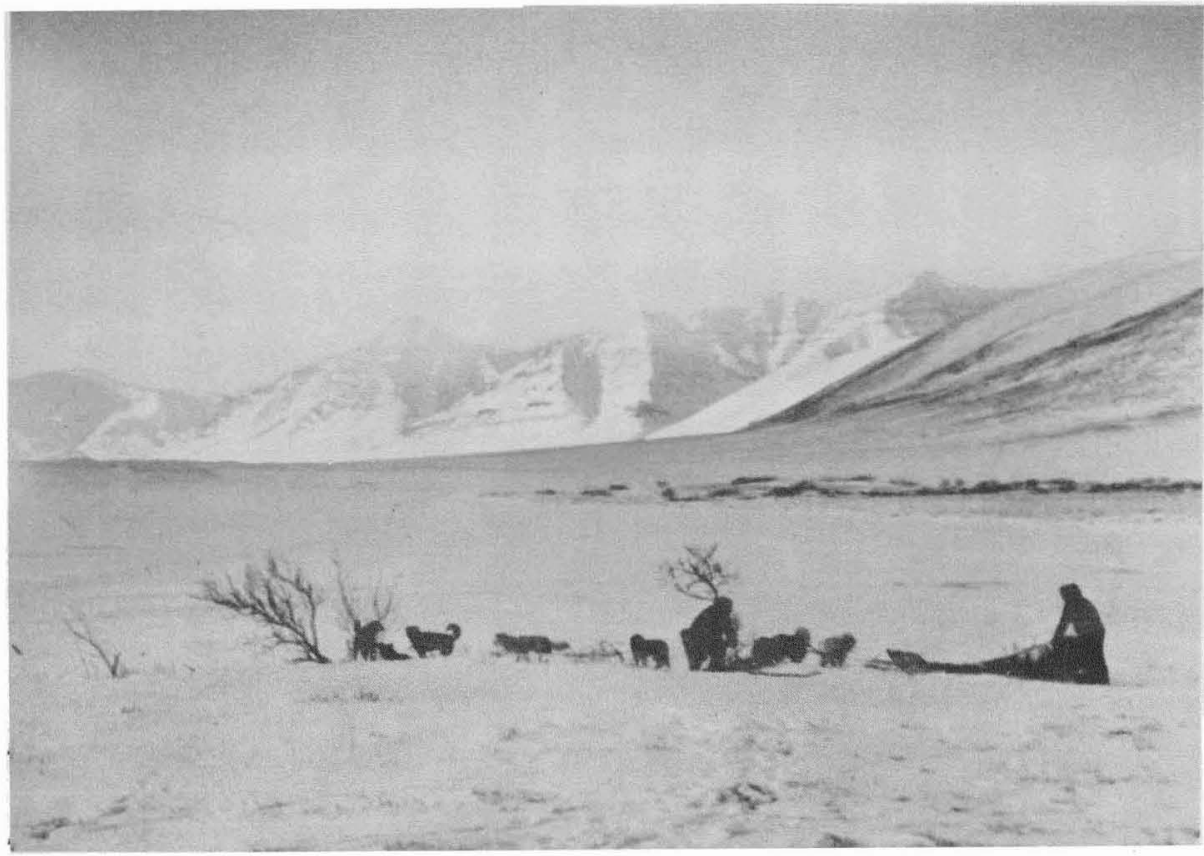

Fig. 3. Travelling north up the Anaktuvuk valley, just beyond the divide, 27 April 1949.

The Nunamiut Eskimo in particular have contributed to whatever success this work can claim. Not only did they do all within their power to assist me, but have made the time spent in their country an unforgettable experience through their hospitality and companionship. Mr. Homer Mekiana, a Point Barrow man who married a Nunamiut woman, and who has lived for many years among the Nunamiut, contributed greatly in several ways. Having been educated in the Point Barrow Native School, he was able to do much to clear up difficulties with the Nunamiut dialect. He has kindly checked the spelling of all Eskimo words given, and has read the manuscript for accuracy as to details of the life and customs of the Nunamiut. To Paneak, Maptigak, Inyualuruk, Kakinya, Ahgook, Ahkmalik, Pilala, Akurak, Ahngak, Aknaniak, and many others, go the best thanks for their aid in obtaining specimens, contributing observations, and, above all, for their excellent hospitality and friendship.

The biological interest of the Anaktuvuk Pass region is now widely recognized. Dr. Iaurence Irving, of the Arctic Health Research Center, has studied the avian fauna for more than three years; Mr. Vladimir Walters, of New York University, has investigated the fishes, and Mr. Lloyd Spetzman and Dr. George I lano have made botanical studies. During the summer of 1951 numerous field parties entered this region, and it would seem that much valuable information on aretic biology will eventually be obtained.

\section{The: Country}

My own field work has been centred in the vicinity of Tulugak Lake $\left(68^{\circ} 20 \mathrm{~N} ., 151^{\circ} 26 \mathrm{~W}\right.$.). Observations were made along the main valley of the Anaktuvuk and John rivers, from the north edge of the Brooks Range souti 


\section{THF NUNAMIUT ISKIMO AND MAMMALS OF THF ANAKTUVUK PASS RFGION}

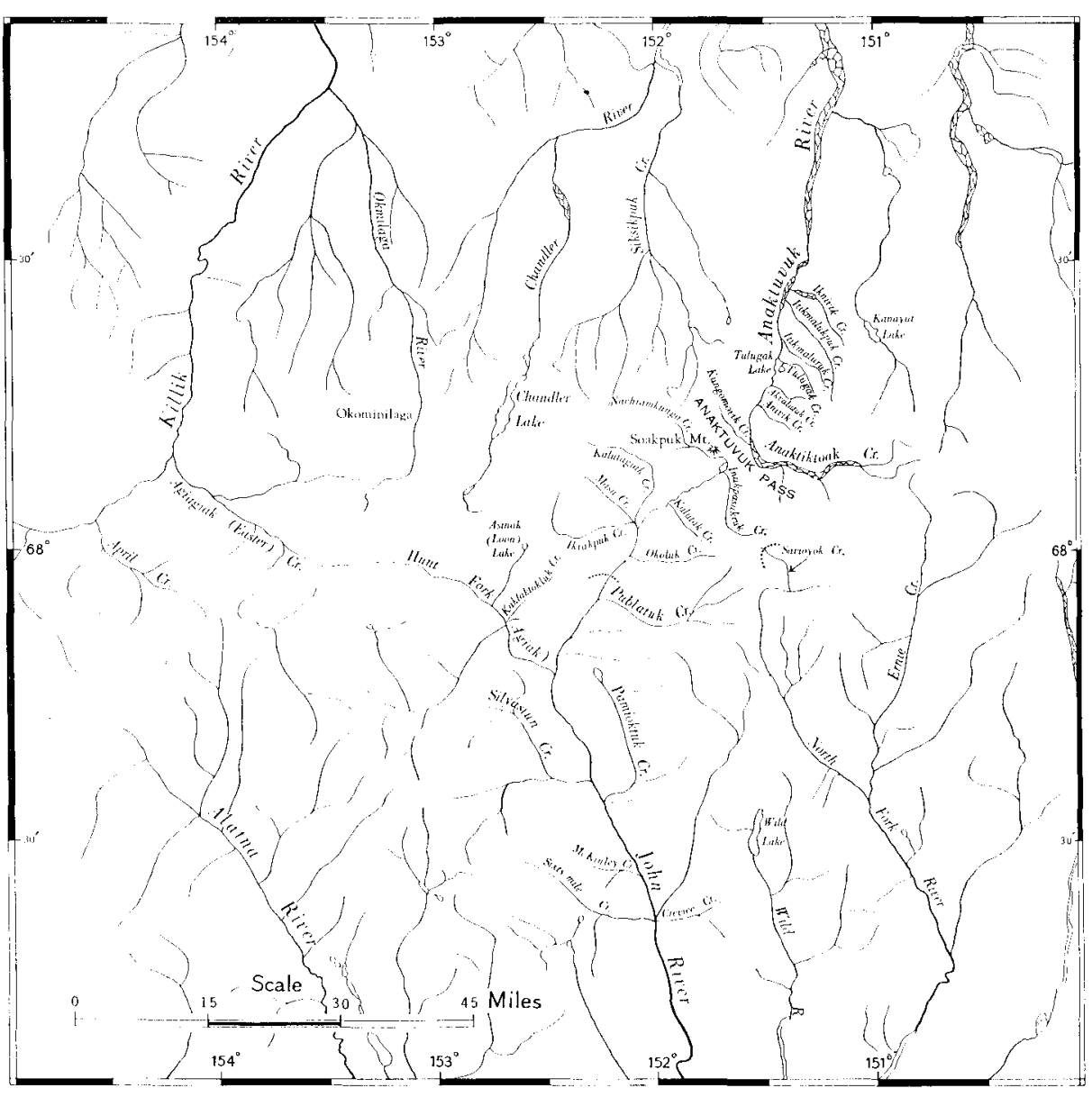

Fig. 4. Sketch-map of the drainage of the Anaktuvuk Pass region, giving local names. Dotted lines on the John River and on Savioyok Creek indicate the northern limits of spruce timber.

to Hunt Fork, a distance of about fifty miles. To the east, collections and observations have been made in the Savioyok valley, a part of the North Fork drainage of the Koyukuk; material and information were obtained from as far west as the Killik (Kitlik)' River.

\section{Physiography}

The mountains of the Brooks Range in the Anaktuvuk Pass region reach an altitude of from 6,000 to 7,000 feet and are composed mainly of Noatak Conglomerate overlain by Lisburne Limestone; geologically, they belong mainly to the Mississippian Age. These mountains, were apparently cut from a former plateau, and are much croded.

Rocks outcrop in many places in the glacial till of the main valley through which meander the Anaktuvuk and John rivers. This broad valley (Figs. 3,

${ }^{1}$ Atthough the Eskimo name is Kitlik, the accepted map spelling is Killik. 
5, and 9) forms a passage of two to four miles in width across the Brooks Range and is an important migration route for various mammals and birds as well as for the Eskimo. There are many glacial-moraine lakes, alluvial terraces, and ground moraines on the valley floor, which, at the divide, reaches an altitude of about 2,000 feet only. Sand dunes occur in places along the Anaktuvuk River. Numerous creeks, dry except during the spring thaw, tumble in steep, rocky beds from the mountains into the valley. The Anaktuvuk enters the main valley from the east, at an altitude of about 2,500 feet and flows northward to the Colville, which in turn empties into the Arctic Ocean. The part of the Anaktuvuk lying to the east of the main valley is called by the Nunamiut Anaktiktoak.

Brooks (1906, p. 102) has described the Anaktuvuk valley and pass: "This pass is only a few miles from where the range falls off to the piedmont plateau on the north, and the Anaktuvuk soon leaves the mountains. The intermontane part of its valley is wide, with abrupt walls, and is only about 15 miles in length, in which distance the river descends over 200 feet. Leaving the mountains, it enters a broad basin 40 miles in length, which has been incised in the Anaktuvuk Plateau and which receives several tributaries." Schrader (1904) has discussed several features of this country.

The John River enters the main valley from the west but a few miles south of the Anaktuvuk, and flows south to join the Koyukuk River, a tributary of the Yukon. The part of the John River which lies to the west of the main valley is called Nachramkunga (from genitive forms of nachrach, "divide", and kook, "creek") by the Nunamiut.

In the main valley certain springs and seepages remain open throughout the winter. Tulugak Lake is fed by such springs, which maintain a temperature slightly above freezing all year. Open creeks are also found in the winter in the Savioyok valley. There are no glaciers in the Anaktuvuk Pass region, but some snowfields persist all summer. There is a considerable area of Aufeis, or heavy ice deposits, in the Savioyok valley.

\section{Climate}

Although in the winter some days are made unpleasant by severe winds from the north (the Koyukuk Indian name for the lower John River is Atchenak, "blowing hard"), the region is not excessively cold. The temperature rarely falls as low as $-50^{\circ} \mathrm{F}$. The annual precipitation is only a few inches. The spring and summer weather are delightful, with cool, clear days. On approaching timber, farther south, the precipitation increases rapidly, resulting in deep winter snows. This is also the case in the timbered Savioyok valley to the east; the change in amount of precipitation is very striking as soon as the divide near the head of Inukpasukruk Creek has been crossed, at an altitude of about 4,500 feet, and the descent started into the country drained by the North Fork.

Since the generally sparse snow becomes firmly packed during the winter by the strong winds, the Anaktuvuk Pass country is very favourable for travel by dog team. Snowshoes are often unnecessary, unless approaching the 


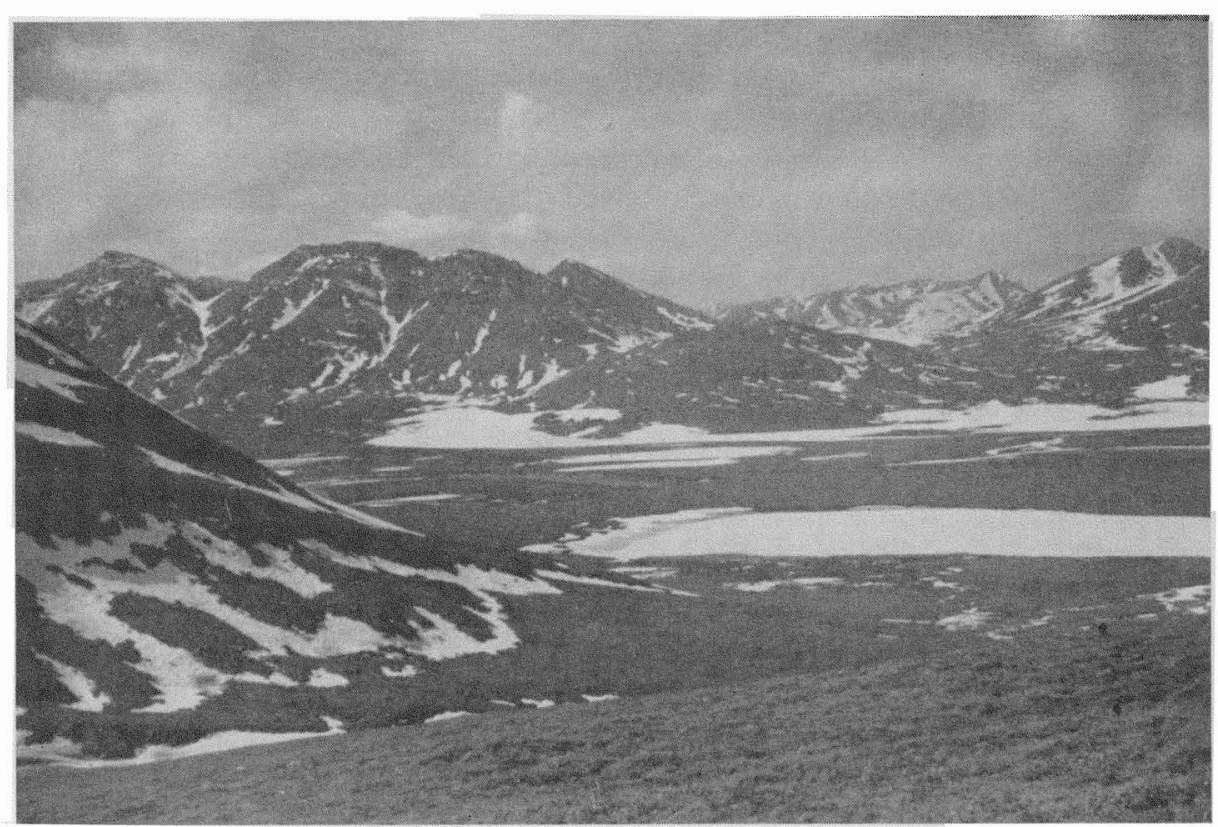

Fig. 5. Anaktuvuk valley, looking west, with Tulugak Lake in the foreground, June 1949.

timbered areas. In some places deep drifts are formed, but parts of the valley and many of the slopes are blown completely free of snow. The entire region is underlain by permanently frozen soil. In summer this thaws from a depth of several inches in the main valley floor to more than three feet in welldrained, gravelly places.

\section{Vegetation}

During the summer of 1949, Mr. Lloyd Spetzman generously aided me in determining the species composition of various plant communities. A detailed report on the plant ecology of the Brooks Range and the Arctic Slope will be published later by him. I have made plant collections whenever necessary, and am familiar with dominant species within the given communities. All names used in this paper are according to Hultén (1941-9).

The occurrence of three main biotic divisions within a relatively short distance makes this region unusually interesting from a faunal standpoint.

a) The Arctic Slope Footbills (wet arctic tundra) lie to the north only a short distance from Tulugak Lake. The vegetation here consists of tundra meadow plants, with some willow growth along watercourses. In some localities (e.g., Umiat on the Colville River), arborescent vegetation, mostly Alnus crispa (Ait.) and Salix spp., becomes dense and luxuriant, but this is of rare occurrence so far north.

b) Arctic Mountains (dry alpine tundra). From just north of Tulugak Lake south to the limit of spruce timber, a distance of about forty miles, a variety of plant communities occurs.

The vegetation of the main valley consists of tundra species, with sedges predominating. These include Carex Bigelowii Torr. et Schwein., C. aquatilis Wahlenb., and Eriophormm spp. Typical heath-moors occur where the soil is drier; pre- 


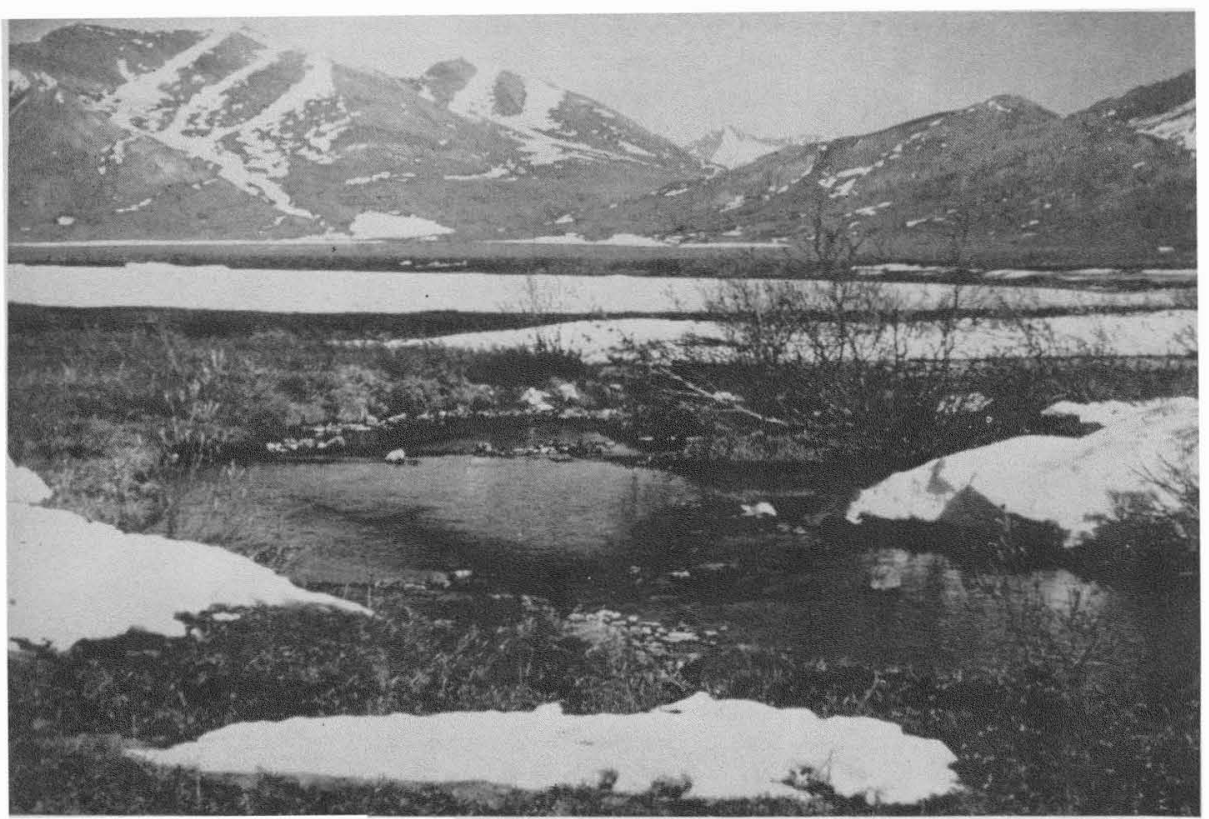

Fig. 6. Springs at the south end of Tulugak Lake, late May 1949.

dominant species here are Cassiope tetragona (L.), Ledum palustre var. decumbens Ait., Rbododendron lapponicum (L.) Wahlenb., Eimpetrum nigrum L., and Vaccinium Vitis-idaea L.

The river and creek banks are covered by heavy stands of willow, including, among others, Salix alaxensis Cov., S. Richardsonii Hook., S. arbusculoides Ands., and $S$. arctica Pall., with a varied undergrowth of Equisetum spp., mosses, and lichens. Birch-willow communities of Salix spp. and Betula nana L., with undergrowths of mosses and lichens, occur in drier habitats.

The dry, rocky mountain slopes support little vegetation other than I)ryas octopetala L., which also occurs on moraines and alluvial fans. South-facing slopes are covered with Dryas, with other species interspersed, while the north slopes support a Cassiope-lichen community, in which Cladonia spp. are important. Therofon Richardsonii (Hook.) is a very common plant of moist drainage areas, usually associated with various mosses. The higher peaks are barren.

Solifluction terraces in the mountains support a dense growth of vegetation. In such places occur Salix spp., Iryas octopetala, Potentilla biflora Willd., Poa glauca Vahl, P. pratensis L., Carex scirpoidea Michx., C. Bigelowii, Kobresia simpliciuscula (Wahlenb.), and Polygonum viviparum L., among others. Earth-surface movements, which are important in the region, have been discussed by Troll (1944).

Sedge-bogs are found in and around semi-permanent shallow pools of water in favourable places at altitudes to about 3,000 feet. Characteristic plants are Equisetum pratense Ehrh., E. variegatum Schleich., Carex aquatilis, C. membranacea Hook., and Eriophorum angustifolium Honckeny.

In some areas the lower hillsides are covered by tussock ("niggerhead") tundra, the predominant plant being Eriophorum vaginatum spissum (Fern.). Local, often pure, stands of various plant species occur, including Alnus crispa, and Populus tacamabacca Mill., none of which is large enough to be important.

Mosses form an important part of the plant community in almost every habitat. Rhytidium rugosum (Hedw.) (ivrok, "roof moss") grows around marshy areas, in 
somewhat higher places, forming a dense cover, and is often associated with Dryas, Salix spp., and lichens. It is found in moist areas to about 3,500 feet on the mountain sides. In certain areas, particularly around the flowing springs near Tulugak Lake (Fig. 6), Hylocomium splendens (Hedw.) forms the greatest part of the ground cover; it is often found under Salix arbusculoides. Dicranum elongatum Schleich. (iparok, "wick moss") grows commonly around willows, forming hummocks, and is found in the main valley in the drier areas. Sphagnum rubellum Wils. occurs in various places, but is not abundant. Pbilonotis fontana (Hedw.), Poblia Wablenbergii (Web. and Mohr), and Cratoneuron filicinum (Hedw.) grow in wet areas along the flowing springs, and are of ten semi-submerged.

c) South Slope of Brooks Range (spruce forest). Just north of Publatuk Creek, in the main valley, the spruce timber, Picea glauca (Moench), begins. Balsam poplar and birch, Betula resinifera Britton, occur here; the first birch is found near the mouth of Publatuk Creek. This is the typical upland spruce forest of interior Alaska. To the south, spruce trees gradually occur at higher altitudes, and the forest acquires an even density. In the vicinity of Crevice Creek, the north-facing slopes support little or no spruce, although all south-facing slopes are densely covered.

A heavy spruce stand is found in the Savioyok valley (Figs. 7 and 8 ), representing the northernmost extension of the species in the region. Here there are trees with a base diameter of as much as 24 inches. Salix alaxensis reaches a height of about 20 feet, and other species of willow form dense stands in the river bottom. Alder is abundant, balsam poplars occur in small numbers, but Betula resinifera is absent.

These various plant communities will be mentioned specifically, later, in connection with the habitats of certain mammals. Mammals and birds from both tundra and forest arc observed from time to time in the northern mountain region. This allows unusual possibilities in the number of species of mammals that may be found. Irving (MS.) has discussed some of the ornithological features of this region.

\section{Thi: Prople}

The local Eskimo are nomadic caribou hunters, who call themselves Nunamiut; this name, in their own dialect, means "people of the land", and corresponds to Nunatarmiut (Larsen and Rainey, 1948), and to Nunatagmiut (Stefansson, 1914). Larsen and Rainey in 1948 (p. 24) reported that the Nunatarmiut had long ago abandoned the region to the north of the Brooks Range. However, Solecki (1950) pointed out that a small group of these people survived in this region, and at the same time summarized from the literature all available information concerning them. On the other hand, the existence of these Inland People was never lost sight of by the coastal Eskimo, particularly at Wainwright and Barrow, and by others acquainted with the Brooks Range region.

While it is true that very few of the Inland People survive in their ancestral hunting grounds, a single group of 71 people still remains. There are 12 separate families, but in 2 the mother is no longer living. There are 8 unmarried girls (including one widowed at 22 years of age), 6 unmarried young men, and 34 children. There is also one unmarried woman of about 40 years.

I was present in the summer of 1949 when the Killik River segment of this group joined the others at Tulugak Lake. They came because of better trade facilities, and because of the hope that their children could be taught English. 
THE NUNAMIUT FSKINIO AND MAMINALS OF THE ANAKTUVUK PASS REGION 155

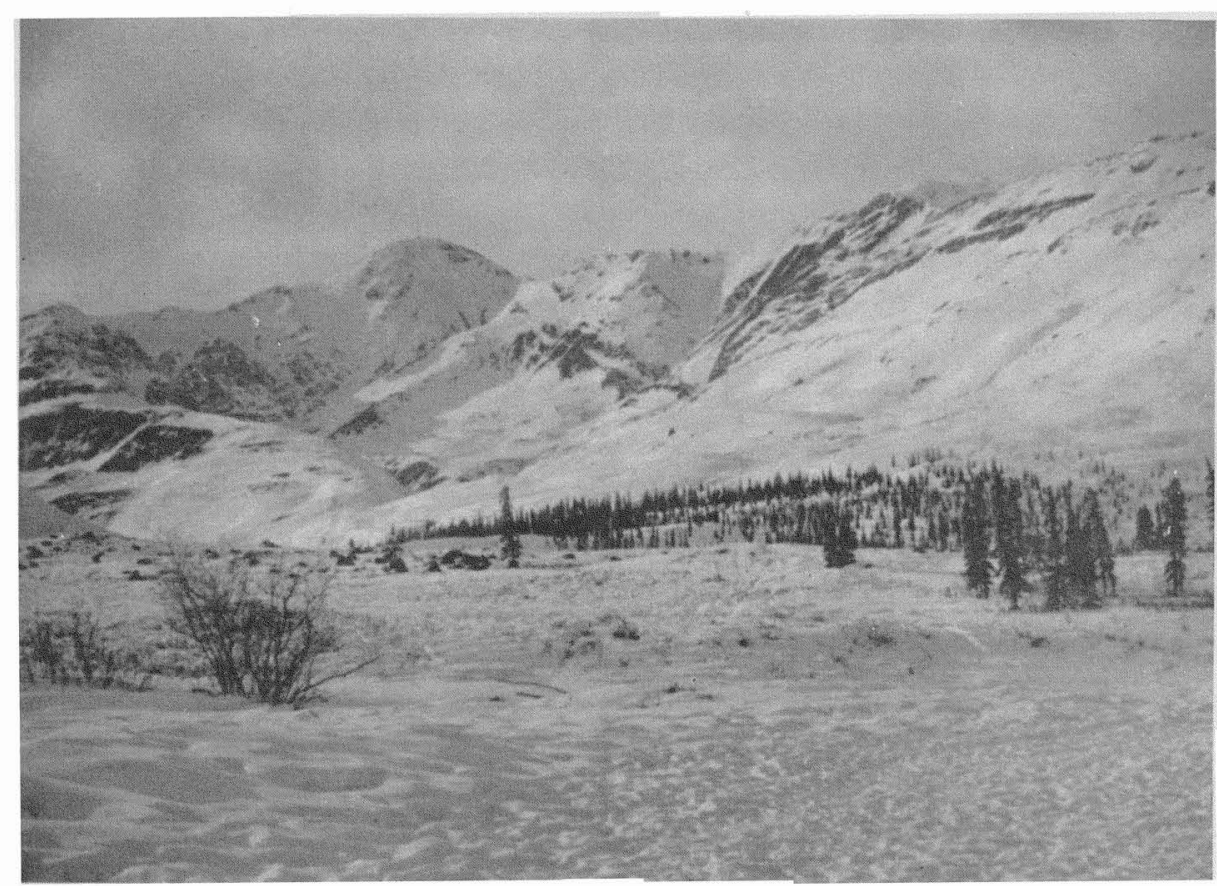

Fig. 7. Last of timber in the Savioyok valley, 3 April 1950.

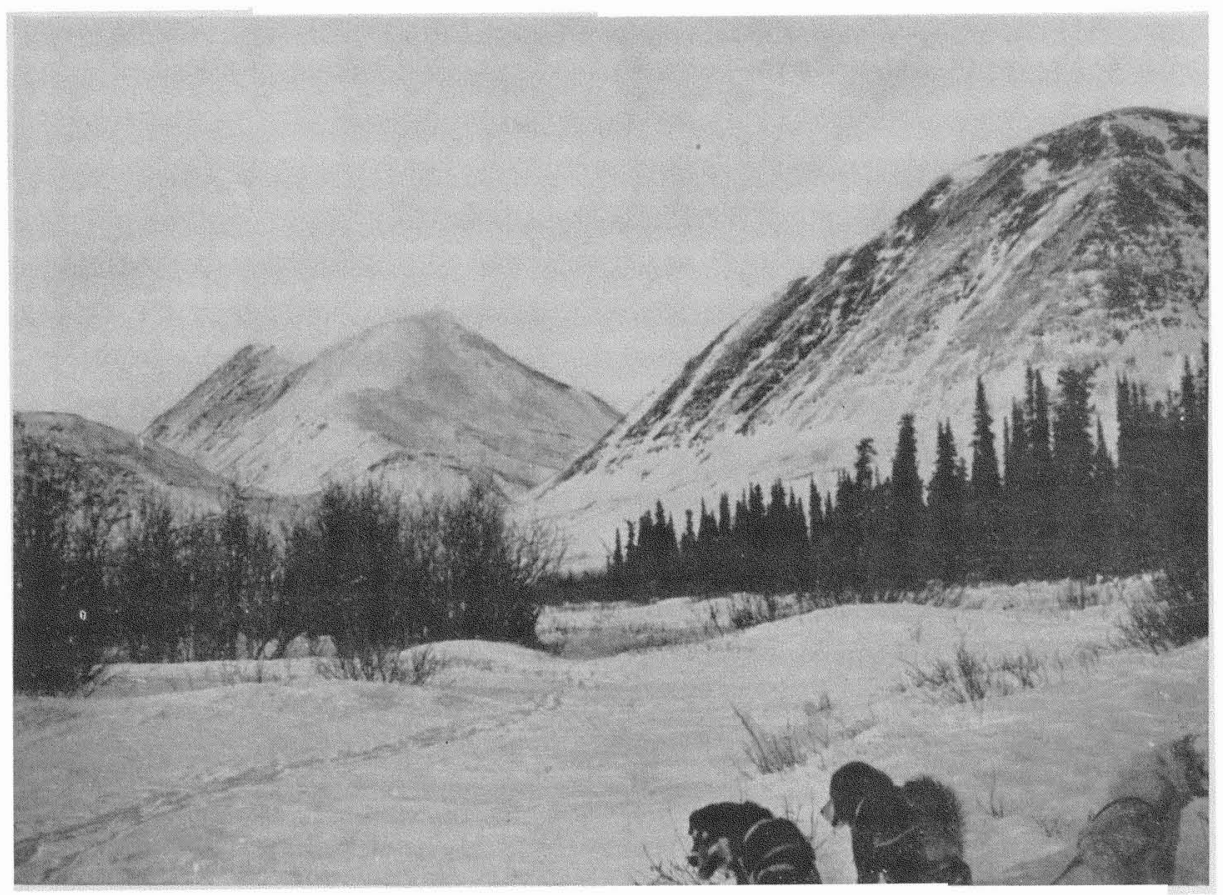

Fig. 8. Savioyok valley, looking north, April 1950. 
Rausch in ARCTIC (December 1951) 4(3). Copyright 1951, Arctic Institute of North America. Used by permission.

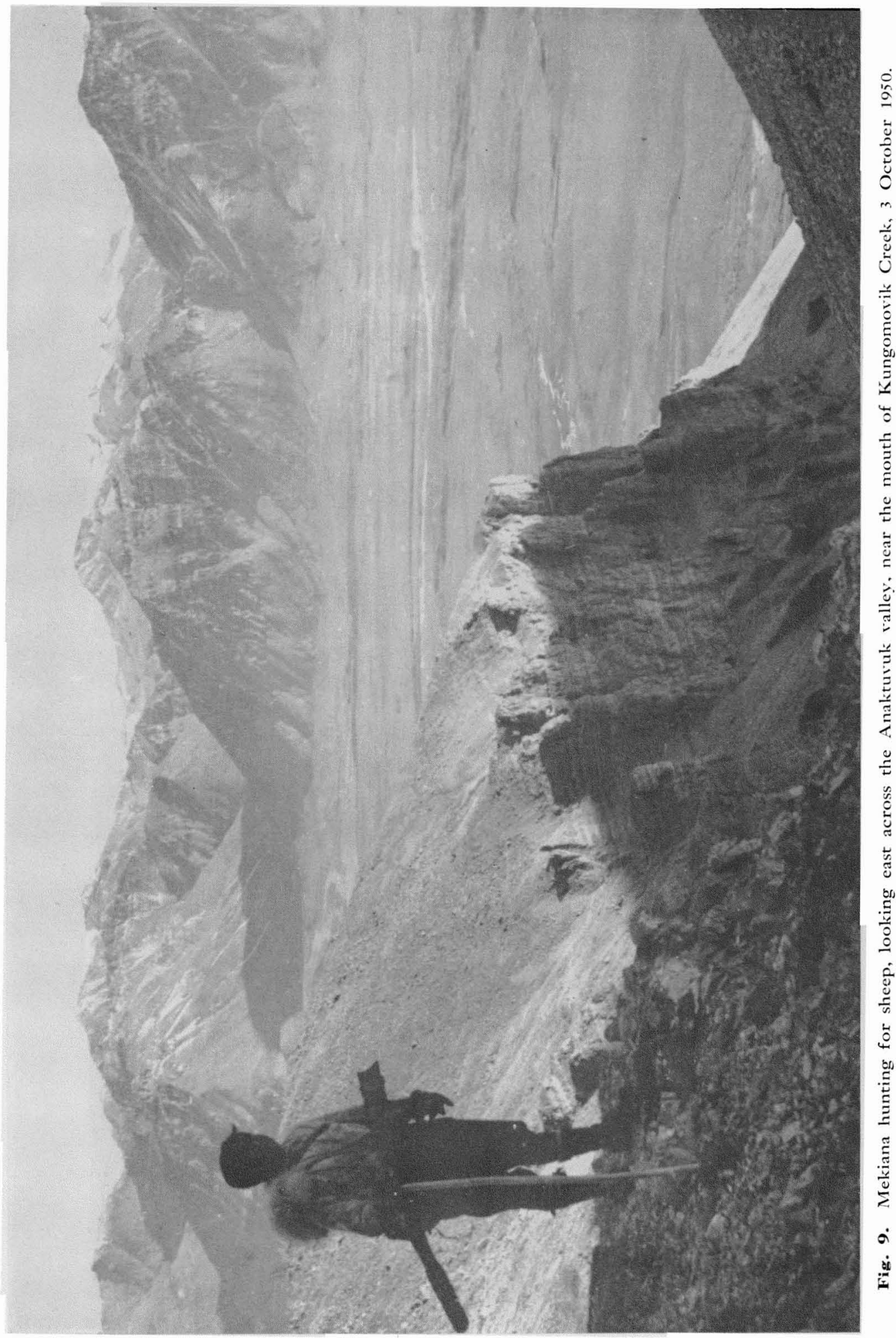


At that time, except for the use of firearms, these people apparently lived as they had done for centuries. They knew no English and existed almost exclusively by hunting. Since 1949 these Eskimo have undergone a very marked change in their way of living. Although still nomadic, and still largely dependent on hunting, they are gradually becoming adapted to the white man's economy. In the spring of 1951 a post office, ensuring regular monthly mail deliveries, was established at Anaktuvuk Pass. This is the first tangible connection these people have had with the "outside world", except for occasional transient traders. Further, the establishment of this post office tends to localize the people, and this has a strong effect in reducing their nomadic hunting. Although no school has been established as yet, several of the people have made rapid progress toward learning English.

It is known that the Nunamiut differ physically from the coastal Eskimo. They are often tall, and have narrower faces with a thinner, high-bridged nose (Fig. 1). In general their facial features are less mongoloid than those of the coastal Eskimo. Seltzer (1933, p. 347) concluded that their physical features "clearly betray the presence of considerable Indian blood that must have entered this group in comparatively recent times." I arsen and Raincy (1948, p. 36), on the other hand, stated that: "We do not know whether the physical type of the Nunatarmiut has been influenced by contact with the Indians or whether the tall lean Nunatarmiut, with the narrow face and the long, high-bridged nose, was originally different from the coast Eskimo." I have been told by these people that in the old days the Nunamiut men would occasionally take an Indian wife, but that the reverse was never true. The Nunamiut consider themselves to be superior to the Indians, with whom they formerly had frequent conflicts. In any case, the Nunamiut are a fine physical type, well suited to their mountaincer-hunter cxistence.

The present-day Nunamiut are a cheerful, hardy people, reserved in the presence of strangers, but demonstrative enough among themselves. They stoically endure pain and hardship, but the capacity for great depth of feeling cannot be doubted by anyone who knows them well. The words of some of their songs indicate unusual aesthetic appreciation of the natural beauty about them. Since they have had relatively little contact with the white man, they largely retain the virtue of honesty, and often cache their most valuable belongings for several months of the year without fear of theft. They have no community organization; each man is on a level with every other. The women apparently have a position equal to that of the men, and the family unit is very strong.

Large families are the rule, and the birth rate is high. A high rate of mortality may result when there is an outbreak of some "white man's disease", such as measles or whooping-cough. During the last three years, there have been eight deaths: two young men died of pncumonia following influenza, two infants died of whooping-cough, two children of dysentery caused by Shigella paradysenteriae, and two children from unknown causes. The people have so far escaped the ravages of tuberculosis, which has had such a disastrous effect in coastal Eskimo villages. The incidence of positive reactors to the 
intradermal tuberculin test is extremely low ${ }^{1}$-in fact, one of the lowest to be found in Alaskan native communities. However, if the Nunamiut abandon their present active outdoor life, this disease may well become prevalent among them also.

\section{Historical Information}

The Nunamiut know themselves to have been for some generations inhabitants of the central Brooks Range, from the region of the Anaktuvuk to the Killik, and they can point out where certain of their ancestors were born in the valleys they now inhabit.

Many years ago, when they were numerous and widely dispersed, they designated themselves according to the region in which they lived and hunted. Thus, there were three main groups: the Tulugakmiut (tulugak, "raven")the people living in the vicinity of Tulugak Lake; the Narivakvukmiut (narivakvuk, "big lake", Chandler Lake)-the people living near Chandler Lake; and the Kitlikmint-the people living near the Killik River.

The Nunamiut made definite seasonal migrations, connected with their hunting and trade with the coastal Eskimo. Formerly, the Tulugakmiut would go by dog team in May to the mouth of the Anaktuvuk River, where they had cached their skin boats (umiat) the previous autumn. Here they left their sleds, and after break-up took their dogs and other possessions, and travelled to the mouth of the Colville River, to a place called Nikilik (from Nikilivik, "white-fronted goose"), the Nirlik of Stefansson (1914). At Nikilik they were met by Point Barrow people, who came for the purpose of trading. In this way they obtained seal oil and seal skins, and later, articles which the coast people had traded from the whalers. In August they returned to the mouth of the Anaktuvuk, hunted and fished until freeze-up, and then returned to the mountains to spend the winter in hunting.

Schrader (1904, p. 35) considered Nikilik an important settlement. Stefansson $(1913 ; 1914)$ met some of the Inland People at Nikilik. The grandchildren of one of the more prominent of the Inland men, Pannioluk, mentioned frequently by Stefansson, are among the remaining Nunamiut in the Brooks Range. One of these, a young woman of twenty-four, also bears the name Pannioluk.

The Kitlikmiut cached their skin boats at the head of the Ikpikpuk, to which they portaged from the mouth of the Killik. In the spring they travelled to the neighbourhood of Barrow (Otkiavik, "place of owls") ${ }^{2}$ to trade. They usually camped near the duck-hunting station, Piknik, east of Barrow Village. Late in summer they returned south and came back to the Killik after freeze-up. I do not know which route was taken by the Narivakvukmiut.

Winters were spent in hunting, and the Nunamiut moved according to the caribou migrations, never staying long in one place. The Kobuk people

${ }^{1}$ This test was administered by Dr. Wendell C. Mathews, Tuberculosis Consultant, Alaska Department of Health, and myself during early September 1951. At this time we vaccinated all non-reactors against tuberculosis by the BCG method.

"According to Mr. David Brower, of Barrow Village, this name is correctly Okpinitk (from okpik, "snowy owl", and $v i k$, "place"), but was changed to the present form during his father's time. 
from the south occasionally came to Hunt Fork for trading, or even as far north as Kungomovik Creek (Kungomovik, "gathering place"), just above the head of Anaktuvuk River. The Kobuk people were mainly interested in obtaining sinews and winter caribou skins. They brought the first white man's food to the Nunamiut. Guns were obtained by trading long before there was any direct contact with the white man.

The present-day Nunamiut follow essentially the old ways, but they no longer make the seasonal journeys to the coast for the purpose of trading, since modern transportation has made available to them such things as they are able to purchase. The summer months are spent in a relatively permanent camp; that is, the people camp in a general area, but the tents are moved a short distance every few weeks in order to ensure sanitary surroundings. During the summer, aside from the necessary hunting and fishing, the men overhaul equipment and make preparations for the coming winter. Dances are often held, particularly when there is unusual success in hunting, or on some other special occasion. For these dances, two large drums are used, three to four drummers at each. The style of dancing is similar to that seen along the Arctic Coast.

The winter is considered the best time of the year. The people do not, as reported by Solecki (1950), winter in the Koyukuk River village of Bettles, but travel widely in search of game. They are excellent hunters, and the wolf-bounty is their most important source of cash income. Wolf skins are sold also to the coast people, who are unable to obtain sufficient wolves for parkas.

\section{Dwellings}

The typical Nunamiut dwelling is a portable structure made of caribou hides stretched over a willow frame. The willows are obtained from the south, where they grow tall and slender. This type of house is called itchelik (from itchet, "hide used for cover") or kalukvik, referring to the frame (Fig. 10). It has a round to oval base, usually about twelve feet in diameter, with the highest point of the ceiling five or six feet above the floor. The house frame has a standard structure. The four main sticks, two on each side, and the first to be placed in position when the itcbelik is being erected, are called tupkotat. The two sticks framing the door are called palitchut. The middle sticks, one from each side, running between the tupkotat, are kanagoat, as are all others running from side to side. All sticks running from the back are kilusiat, and all from the front, with exception of the above-mentioned palitcbut, are called salicbat. The thongs binding the sticks together are called kiligotit, while those holding the talu ("door-flap") in place are taluliutut.

About twenty caribou hides are required to cover such a house. Six hides, sewn together in a strip called itchet, are used for the roof. Two strips, of three skins each, called siaktalat, are used for the back, and a strip consisting of two skins, maloagaluk, is used on each side. To the right of the door, in front of the stove or fireplace, a single strip, sakutak, is placed. These hides, like most skins used for clothing, are prepared by thorough scraping only. This gives them pliability and they may last for as long as three years as house 
covers. Skins are placed on the frame with the hair-side out. A second cover, now made of canvas, but formerly made of hides from which the hair had been removed, is used to make the structure waterproof. The floor covering in all types of Nunamiut dwelling is of willow branches covered in part with hides. The hide of a grizzly bear is preferred for the door-flap (talu), and this is hung with the fur-side in, but a heavy bull caribou hide is sometimes used. The window (igalik) is often made from strips of the small intestine of the grizzly bear, cleaned and sewn together to form a sheet. In

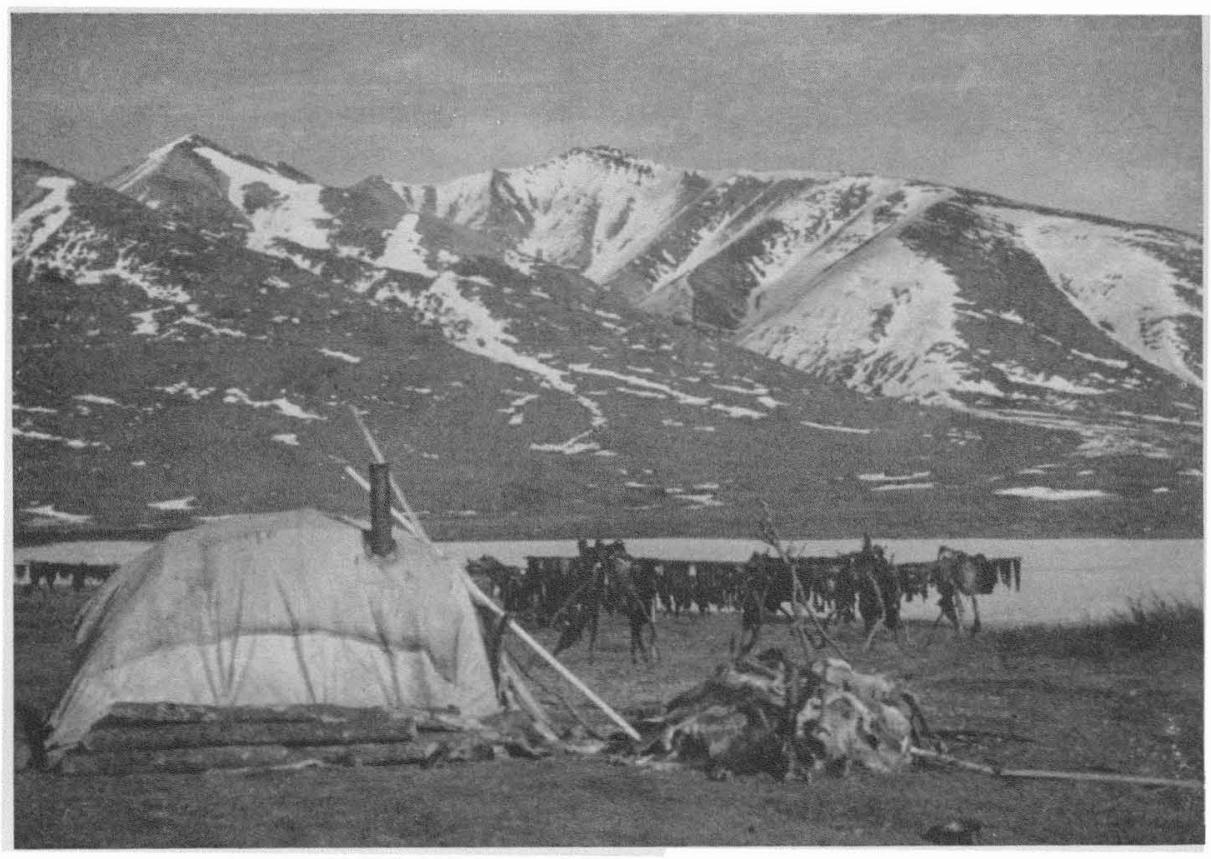

Fig. 10. Nunamiut itchelik, Anaktuvuk Pass, with drying caribou meat in the background, May 1950.

the old days, two caribou skins, from which the hair had been removed by soaking in water, were used.

Solecki $(1950$, p. 145) described the itchelik, but quoted various authors to the effect that several inches of snow were packed over the outside covering for added warmth. Such houses are already very warm, and I have never seen nor heard of snow being added for insulation. I know nothing of the multiple-family house reported by Stoney (1900) in this region.

The itchelik was formerly occupied the entire year regardless of weather conditions; most of the people now live in canvas tents during the summer.

Another type of house, of sod placed over a wooden frame, is sometimes built when the stay in a place is longer. This house, called ivnulik, referred to by Larsen and Rainey (1948, p. 35), is uncommon.

\section{Clothing}

Most of the Nunamiut now wear white man's clothing, especially during the summer months. However, the more essential items of clothing for winter 
wear are made of caribou hide, which for real warmth is superior to anything else available. Caribou hides require little preparation for use as clothing. When the hides are removed, they are spread on the ground to dry. In the summer and fall, when most of the caribou are killed, drying is very rapid and the dried skins can be cached until needed. The hides are then thoroughly scraped, thus removing the superficial lavers and breaking down the fibres to give softncss. For most purposes the soft, white leather prepared requires no further treatment. If a better grade of leather is needed, the hides are smeared with a mixture of brains boilcd in water, or a paste of liver, and rolled up in a warm place over night. The following day the hides are scraped until gradually dried, and this results in a very fine, soft leather. A white clay, called kitik, was formerly used for softening hides. It was obtained from a place of the same name on the Colville River below Umiat. All sewing is done with caribou sinew, and the necessity of saving the long back-sinew has resulted in the development by the Fskimo of a highly standardized method of cutting up these animals.

Boots are made of caribou hide, and there are several styles, depending on season and use. For winter the soles are made of thick neck-hide of fallkilled bulls, with the hair turned in. Inside parkas are made of cow or fawn skin; a heavier outside parka is worn with the hair-side out during the winter. Parka ruffs are made either of wolf or of wolverine fur, with the former being perhaps the more common, particularly with the men. The hides of sheep are uscd for parka trimming, and when caribou are scarce may be used for clothing. They make the best sleeping bags.

\section{Food}

Although certain food items, such as tca, flour, and sugar are now obtained from the white man, the Nunamiut dict is essentially unchanged from that of many years ago. Frozen fish are frequently eaten in the fall and, when they can be obtained, in the spring. Meat forms the great bulk of the diet and the caribou is the main food animal, upon which the Nunamiut depend for survival. Much caribou meat is dried, in both spring and fall, for use when hunting is poor. A considerable amount of meat is eaten raw or raw and frozen, particularly when on the trail. All animals killed are very completcly consumed. Cooked heads of sheep are considered unusually good. The brains (kakisalik) are eaten cooked or raw and frozen. The ligamentum (kauksik) at the base of the skull is eaten raw, at the time the sheep is killed, for its high fat content. The interdigital glands (akunigun) are always eaten raw, and the testicles of rams are cooked. In the old days the women were not permitted to eat any meat forward from the last three or four ribs of sheep or from the front of the hind leg, nor could they eat fat from the body cavity. These customs no longer persist.

Long-bones of caribou and sheep are cracked for the marrow, but are not as completely utilized as they once were, when even the ends were rendered out by boiling. In the fall every effort is made to procure a good supply of caribou rump-fat. In May, whenever caribou are skinned, the larvae of the caribou warble fly, which have reached their greatest size prior to pupation, 
are eaten by the Nunamiut. These larvae are often found in large numbers lying just below the skin on the back, and are eaten alive as they are removed from the small pocket of inflammatory tissue surrounding them. I have found these larvae quite palatable.

Cooking, which has become a more common practice in later years, is done on small sheet-metal stoves. Maptigak, now an old man of about seventy years, stated that he was "old enough to hunt ptarmigan" before his family had any stove other than the old fireplace (sinigun) outlined by a few stones on the floor. Cooking was done then in wooden vessels by adding heated stones.

Larsen and Rainey (1948, p. 31), in discussing the "Nunatarmiut", stated that: "When, for some unexplainable reason, the caribou fail to appear in numbers sufficient for their needs, the Nunatarmiut had the choice of starving or of settling on the coast until the herds returned." This hardly appears to have been the case, since then, as now, they were capable of obtaining other animals in large enough quantity for survival. During the times of caribou shortage, the people eat ground squirrels, marmots, sheep, and fish. Bears are obtained from time to time, but never make up a very important part of the diet. When caribou are exceptionally scarce, the people may move to timbered regions where moose can be obtained in adequate numbers. The abundance of mammal life in the Brooks Range seems to ensure plentiful food, unless hunting success is prevented by a combination of unfavourable circumstances.

\section{Transportation}

The present-day Nunamiut have fine teams of unusually large and powcrful dogs, some of which weigh more than 100 pounds. The Nunamiut have at times been criticized, by those unfamiliar with the conditions, for keeping large numbers of dogs, which naturally require a considerable amount of meat. However, large teams are needed to transport loads over terrain as difficult for dog team travel as that of the Brooks Range outside the main valleys. On one trip over the mountains to the east, which I made with one of the Eskimo, we used ten dogs though we had almost no load, and sledding conditions were at their best. On fairly level ground, as in the main valley, about 100 pounds per dog is considered a suitable load. During the summer months, in the fall before freeze-up, and often on hunting trips in rough terrain, the dogs are used as pack animals. They are capable of carrying very heavy loads in pouches on either side of a caribou-hide pack saddle. I have seen a dog carry the entire fresh hide of an adult bull moose for a distance of more than two miles without showing undue signs of fatigue. Another dog carried a bear hide, which weighed slightly over 50 pounds, about ten miles through new snow, the bottoms of both pouches dragging deeply the entire distance.

The Nunamiut sled has runners made of spruce, from trees obtained in the timbered regions to the south or to the east. A tree which has a pronounced curve just beneath the ground surface is felled and sawn lengthwise into boards. An entire section, after some shaping, is used for a runner, the bent end making the curved front. 
In the old days, spruce was obtained for umiak and kayak frames from the North Fork River valley. The journey for wood was made up the Anaktiktoak, and the round trip from Tulugak Lake required but two days. The frame of the umiak was covered with bearded seal hide, obtained through trade with the coast Eskimo. Kayak frames are covered with caribou hide. The umiak is not now used, but kayaks are used from time to time, particularly for spearing swimming caribou.

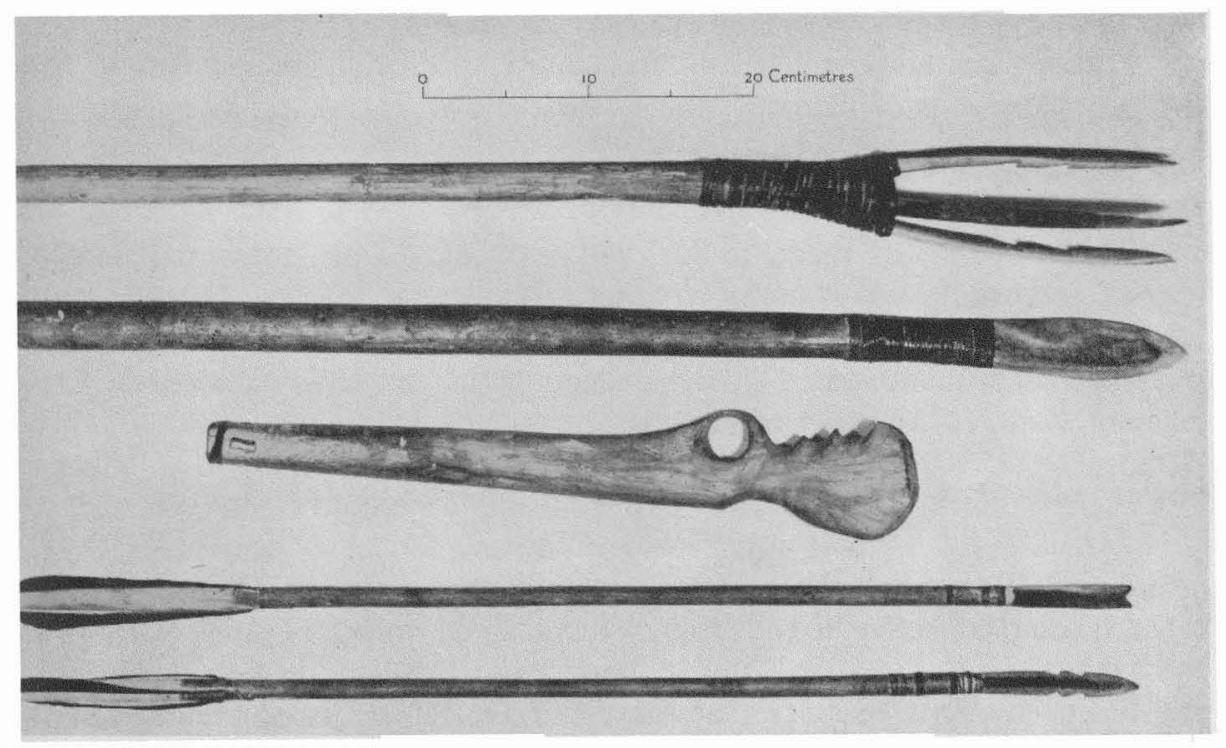

Fig. 11. Nunamiut weapons: three-pronged throwing spear; spear for swimming caribou; throwing stick; bird arrow (uchulik); caribou arrow (natkulik).

\section{Hunting Implements}

The main weapon of the Nunamiut was the bow and arrow. Bows were of two kinds: one backed with sinew (piralik), and one without sinew backing (kiluinak). Certain twigless spruce branches, called $i k i k$, were preferred for making bows. Arrows (see Fig. 11) were preferably made of birch, but spruce was sometimes used. Arrows were of three kinds: a barbed one, for larger animals, particularly caribou, called natkulik; one with two blunt points, for birds, called uchulik; and another with three blunt points, also for birds, called kukulvalik. Arrow points were usually made of caribou horn. Bows and arrows were stained with a bog-iron ore, called ivisak, from a place of the same name on the Killik River. The stain imparts a brick-red colour, and is still used for colouring the wood of snowshoes, sled runners, and other wooden implements. Molting waterfowl were captured by means of a three-pronged spear, thrown with a throwing stick (Fig. 11).

Firearms were secured through trade long before there was direct contact with the white man. Flintlocks were obtained first, followed by guns fired by percussion caps, then the rim-fire .44 , and later the centre-fire .44 . I have 
found .44 rim-fire shells, along with fragments of caribou bones, a few inches beneath the surface of the ground, in old campsites. Several calibres next appeared, including $.45-70, .38-70$, and $.38-55$. The latter is said to have been first obtained in 1908 at Nikilik from the people of Barrow.

The most popular gun today is the Winchester model 94 in .30-30 calibre. Also used are the .25-35 and the .25-20. A few men have recently obtained guns of .257 calibre, which allow much greater success in wolf hunting because of the longer range. The Nunamiut shoot well, and do not hesitate to kill large grizzlies with rifles of small calibre.

Hunting methods will be discussed more specifically in connection with the various species of mammals considered below.

\section{Bronks Range, Mammals}

The observations made so far on the mammals are presented here by species, according to systcmatic order. Nunamiut species-names and any others considered appropriate are included. All prepared mammalogical material has been deposited in the collections of the U.S. National Museum and the National Museum of Canada.

Sorex obscurus obscurus Merriam. Ugnuknak ("like bearded seal"). Dusky shrew.

About 50 specimens were obtained of this shrew, the most common of the three species collected in the Brooks Range. Of these, 14 skins with skulls were deposited in the U.S. National Museum in 1950; another series of similar size has been prepared since that time, and the remainder was autopsied for parasites only. Sorex obscurus seemed particularly abundant around the springs at Tulugak Lake. Here it was trapped at small burrows in the mosses Philonotis fontana and Pohlia Wablenbergii along the water's edge. It was also obtained in vole sets on higher ground in the same arca. Specimens of this shrew were collected in the main valley, but not above an altitude of 2,100 feet; howcver 9 were trapped in spruce timber in the Savioyok valley at an altitude of about 2,500 fect, and 4 were taken on upper Hunt Fork.

Few observations were made on the breeding of this animal. In 1949 a female containing two embryos was collected on June 1, and one containing nine embryos on July 26; a lactating female was taken on July 12.

The molt into winter pelage occurs during September in this region and September specimens show much variation in the molt pattern.

Tracks of shrews are often seen in the winter around wolf-kills and other carcasses, but it was not determined if all species of shrews feed in this manner.

Sorex cinereus ?ugyunak Anderson and Rand. Ugruknak. Arctic cinereous shrew.

On the basis of the first material collected, the cinereous shrew of the Tulugak Lake region and of Umiat was assigned to this form. Anderson and Rand (1945) also assigned two specimens from the eastern Brooks Range to the subspecies ugyunak. After adequate series are obtained, and when com- 
parative material is at hand, restudy of my material will perhaps be justifiable in order certainly to determine the subspecific status of this central Brooks Range form.

The cinereous shrew was not commonly collected, but a good series was taken near the divide between the Anaktuvuk and John rivers. A single specimen was collected at Kanayut Lake. This shrew appears to prefer a somewhat drier habitat than does $S$. obscurus and was taken in higher areas where there was a heavy moss cover beneath willow and dwarf birch. Eleven specimens were obtained near the last spruce timber in the upper Savioyok valley. Sorex cinereus is the smallest of the three species collected.

Sorex tundrensis Merriam. Ugruknak. Tundra saddle-backed shrew.

Tundra saddle-backed shrews seemed to be about as common as $S$. cinerets, and were collected in the same kind of habitat. One specimen was taken at Tulugak Lake, and one on Itikmalukpuk Creek, but the others were obtained from farther south, on higher ground. None was collected in the timbered country. The animals preserved are in winter pelage.

This species is known to occur on both sides of the Brooks Range (Hall, 1929), but in some years, at least, it must be uncommon. In spite of intensive trapping during 1949, no specimen was obtained, either in the Brooks Range or as far north as Umiat, or along the Arctic Coast.

Of 16 shrews collected during October 1950, near the head of the John River, in the main valley, 7 were S. cinereus; 7, S. tundrensis; and 2, S. obscurus.

Ursus richardsoni Swainson. Achlach. Arctic grizzly.

The arctic grizzly (Fig. 12) is one of the most interesting of the Brooks Range mammals. It is not often seen, since it seems to spend much of the day sleeping high on the rocky mountain sides, and is frightened from the vicinity of Eskimo camps by the howling of the dogs. It is often hunted, which contributes to its wariness.

This animal is widely distributed, and in Alaska its range appears to encompass at least the entire region north of the southern limits of the Brooks Range, including the Arctic Slope. According to Thomas Brower, it is not unusual to see grizzlies at his reindeer ranch on the Alaktak River, near Admiralty Bay; an adult male was killed there in 1949, and three others were seen together early the same spring. I have examined skins from the Kaolak River, about fifty miles southeast of Wainwright, and from the Utukok River, about ninety miles southwest of Wainwright. A young male, about three years old, was shot at Oumalik, on the Arctic Slope, and these bears were not uncommon around Umiat, on the Colville River. The skull of a young animal was obtained from Mr. Lloyd Spetzman who had shot it near Shublik Springs in the Canning River valley. Stefansson and Anderson (1913) collected this bear in northern Alaska, but did not consider it common north of the Brooks Range.

The winter den is usually excavated high in the mountains, but some of these bears also winter on the Arctic Slope. I saw a den, from which a bear had just emerged, near the top of a bluff along the Colville River near Umiat. 
The Nunamiut name for the winter den of bears is sidroak. According to the Inland People, the bears come to the mountains in the fall to den, and move north to the Arctic Slope in the spring.

The bears often enter the dens very late, and some individuals not at all. I collected an old male on 15 October 1950, in heavy snow in the Savioyok valley, and an aged male was killed in the same locality on November 9. The Eskimo saw bear tracks on Ikiakpuk Creek on November 18, and the track of a large bear moving south along the upper North Fork near the end of

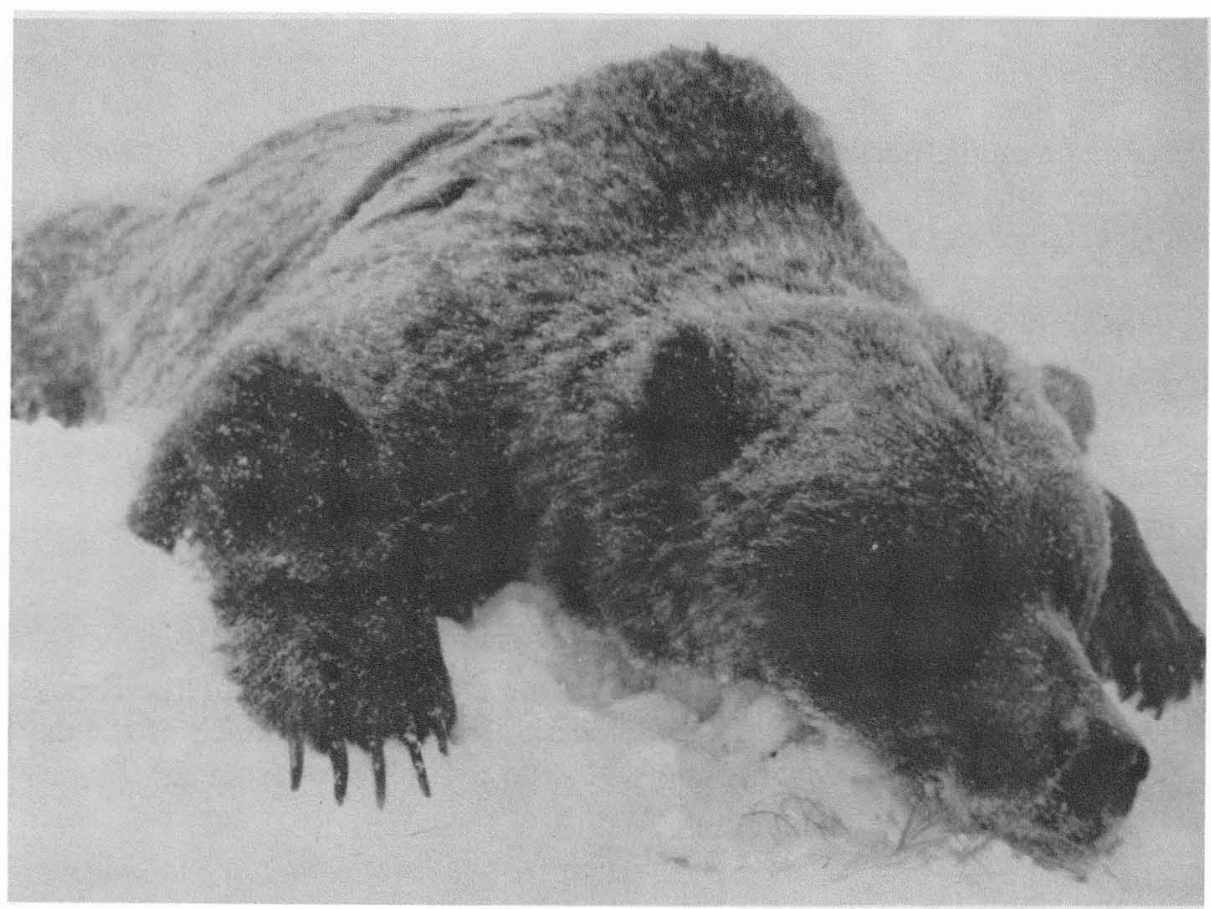

Fig. 12. Grizzly bear, Savioyok valley, 15 October 1950.

November. Tracks are commonly seen in November, but all the bears remaining out appear to be males. In this respect they are perhaps similar to the polar bear. Paneak told me of killing a large male bear on 18 December 1945 , near the head of Hunt Fork. The animal was fat and in good condition, but, according to Paneak, all four feet had been frozen, resulting in hair loss. Bears killed in the winter usually have much ice in their fur. In former times the Nunamiut believed that grizzlies would deliberately enter an open spring in winter, allowing water to freeze in their coat in order to retain warmth.

As reported by A. Murie (1944) for Ursus toklat Merriam, the arctic grizzly emerges from its den in April. In 1949 the first bear was killed by the Fskimo on May 6. On 3 April 1950 I saw the tracks of three different bears in the Savioyok valley; these had been made by an old female with a cub, and by what was apparently a yearling cub. The same day the tracks of a large adult were seen by the Eskimo in Okoluk Creek. In 1951 the first tracks 
were seen on April 13. There is very little food available at this time of the year, for conditions are still very wintry.

For several days after emergence the bears remain around their dens, sometimes returning to them. In this region they feed largely on old wolf-kills or other carcasses. The Eskimo reported that they had seen a bear, during the month of April, trying to dig a wolverine from a burrow in the snow, but it easily escaped. The bears are in poorest condition in June, although many berries from the previous year, and many roots, are available. In July, as vegetation becomes more abundant, they improve in condition.

The feeding habits of Ursus richardsoni compare well with those of U. toklat, as reported by A. Murie (1944). There is no evidence, in spite of the common occurrence of caribou hair in bear droppings, that these animals kill any caribou. It is possible that a few fawns are killed in the spring, but this is unlikely as the fawns are born on the Arctic Slope, where bear density is not great.

No particular effort has been made to collect bear droppings for studies of food habits, but a few incidental observations have been made. During the summer the arctic grizzly is almost entirely a vegetarian, as little animal matter can be obtained unless a carcass or wounded animal is found. The stomach of a bear killed on 19 July 1949 contained a quantity of Equisetum sp. and some caribou hair. Therofon Richardsonii (=Boykinia Richardsonii), which is common in the Brooks Range, is often eaten, particularly the roots. In the fall I have sometimes seen droppings composed almost entirely of cranberries (Vaccinium Vitis-idaea $\mathrm{I}$.), and numerous excavations can be found in creek beds and on sand bars where bears have dug for the roots of Hedysarum sp. These roots, which are abundant, are often eaten by the Fskimo, who call them masu. Voles (mainly Microtus miurus) were numerous during the time of this study, and large areas were frequently seen where bears had torn away the moss in their search for these rodents. Ground squirrels are dug out, especially in the fall, and ground squirrel hair is often seen in bear feces. The stomach of a bear shot at Oumalik on 20 July 1949 contained four lemmings (Lemmus trimucronatus), the digital bones of either an adult caribou or reindeer, and a considerable quantity of Carex $\mathrm{sp}$. This animal was killed shortly after a heavy mortality of lemmings along the Arctic Coast (Rausch, 1950a), and dead lemmings were abundant.

Ursus richardsoni is not an exceptionally large bear, although it is a very powerful animal. A large male, killed on 15 October 1950 when it was fat, weighed 580 pounds. According to the Nunamiut, this bear was as large as any they had seen; it measured $1,850 \mathrm{~mm}$. in total length, and the length of the hind foot was $303 \mathrm{~mm}$. A very old bear (ahgayukaksrapiagatak), killed on 9 November 1950, measured about 1,900 mm. in length, with a hind foot length of $280 \mathrm{~mm}$., and weighed only 365 pounds. This bear, the oldest obtained, was in poor condition, possibly as a result of old age, and its tecth were very badly worn and broken.

The arctic grizzly shows considerable variation in colour. This may be partly relative to time of year, but is mainly due to individual variation. Two 
female cubs, one of which was dark and the other light, were killed with their mother on 11 July 1951 by the Eskimo on Anaktiktoak Creek. ${ }^{1}$ In some animals, head, neck, and shoulders are very pale, sometimes almost buffy-white, and the legs and belly are dark brown. In the fall the hair is shorter and much darker, although the dorsal hairs have lighter tips and later become lighter throughout. Some animals, such as the old bear mentioned above, are very pale, even in the fall.

The claws of the arctic grizzly are long and moderately arched; they range from dark brown through horn-colour to white. The longest claw of the fore foot measures from 53 to $77 \mathrm{~mm}$., with an average of 60 to $70 \mathrm{~mm}$.

A good series of skulls, several with skins, has been obtained, and is now in the collections of the U.S. National Museum and the National Museum of Canada. Rather striking variation is seen in some of the skulls, but I attribute this to normal age and sex differences, and to individual variation. From a study of other skulls available from this locality, it would seem that skull growth and changes in skull conformation continue throughout the life of the animal. The most aged animals examined showed the greatest extremes in skull measurements. The skulls of these bears have been compared with those of $U$. toklat, from which they differ in minor detail. Minor differences were also observed when these skulls were compared with those of unidentified bears from Jarvis Creek, in the Biological Survey Collection. The significance of such differences cannot be determined from the limited material now available. Table I gives skull measurements for $U$. richardsoni.

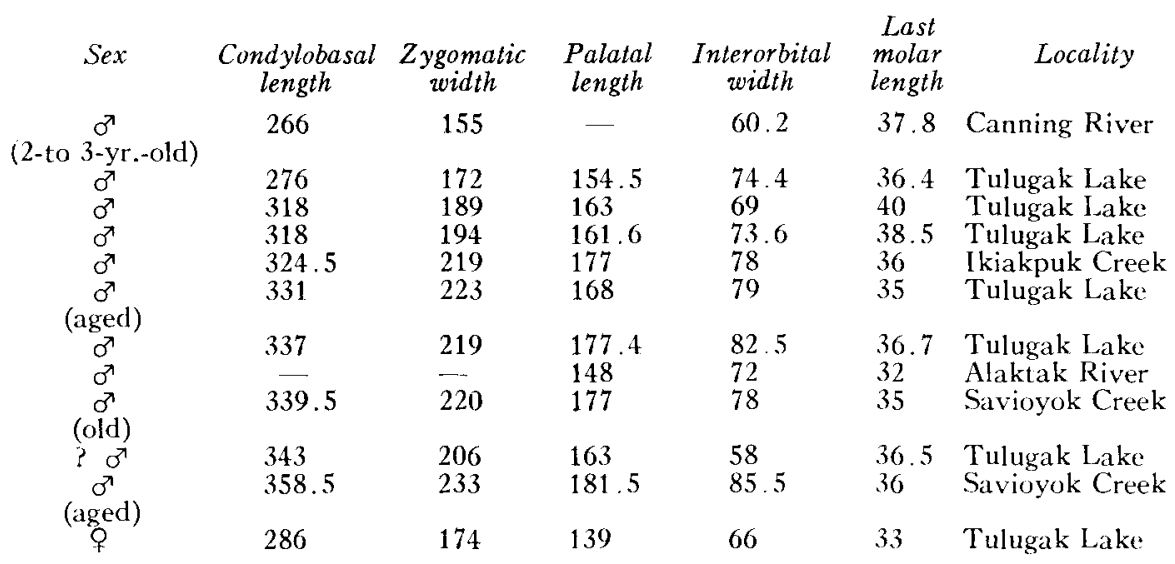

Table I. Skull measurements of 12 specimens of Ursus richardsoni (in millimetres).

The skull of a cub, killed on 23 September 1948, allows the following observations on the rate of irruption of the permanent dentition:

The permanent first upper incisors are in place, and the second incisors are just emerging. The deciduous third incisors are still present, although the points of the permanent teeth are visible. The deciduous canines are still in place, but the permanent canines can be seen coming through anterior to them. On the right side, two premolars are present, and on the left there are three. The first upper molar is in

${ }^{1}$ The skins of these cubs have been deposited in the U.S. National Museum. 
place, but the second has not yet appeared above the level of the palatine bone. The alveoli of these extend backward into the zygomatic space to slightly beyond the posterior limits of the median part of the palatine bone. In the mandible, the first two permanent incisors are present, and the third is coming through on each side. The left deciduous third incisor is still in place, but the right one has been lost. The canines are in a state of development similar to those of the maxillae. There are three premolars on the left, and two on the right. The permanent first molar is in position, but the second is still partly imbedded at its posterior end, although the entire tooth is visible. The third molar is completely concealed. The condylobasal length of this skull is $199 \mathrm{~mm}$., and the zygomatic width is $119 \mathrm{~mm}$. The degree of elimination of the posterior extension of the alveolus of the last molar is closely associated with the age of the animal.

The Nunamiut are very successful in hunting the grizzly bear, although no great effort is made to obtain them. Eight bears were killed in the Tulugak Lake region in 1948; 5 in 1949; 11 in 1950; and in 1951, up to the middle of September, only 4. Three animals of the same size, apparently two-year-olds, were killed together in 1950 as they travelled to the north over a snowfield west of Tulugak Lake. Four adult-size bears were observed together by the Eskimo during early September 1951.

These grizzlies are ordinarily killed with small-calibre rifles, in contrast to the usual practice of the white man. The Nunamiut rarely kill bears with any gun larger than the .30-30, and both .25-35 and .25-20 are commonly used. Paneak claims to have killed 9 of these bears with a .22 Hornet; only one came towards him, and he killed it with a second shot in the head; onc besides these, escaped. It is the practice of the people to approach a bear as closely as possible before shooting. They often shout first, so that the bear, if only wounded, is not likely to run in their direction.

Even before modern rifles were available, I have been able to learn of only two Nunamiut fatalities caused by bears. Maptigak, now an old man, told of a case where four hunters went after a bear during the winter along the Colville. One man shot it with a flintlock gun, but the bear had much ice in its fur, and the bullet did not take effect. The man was attacked and killed. The grandfather of Inyualuruk, one of the older men of the group, was killed by an ice-covered bear as he attempted to spear it. This was before Inyualuruk's father was old enough to hunt for the family, so the death brought much hardship. It is of interest that the Indians farther east have a superstitious fear of such ice-covered bears and refuse to hunt them.

In earlier times the Nunamiut observed certain customs and superstitions when hunting bears. For instance, it was unwise to boast about killing bears, since the animals would hear and would not easily then be killed. Stefansson (1914) reported this superstition to be held also by the Eskimo east of the Mackenzie. After the killing of a bear, a gun was called "achlachtun", and had to rest for four days after the killing of a male bear and five after a female, before it could be used for caribou, or it would bring bad luck.

Bears were usually killed with spears in pre-firearm times. According to the Eskimo, the bear spear had a head made from flint or from the forearm bone of a bear, and a shaft about eight feet long. The butt of the spear was placed firmly against the ground, before the bear attacked, and when the animal 
lunged at the hunter, it becane impaled. Some bears were killed by bow and arrow. One man would infuriate the bear until it charged him, and he would then lead it past the hunters in ambush.

Grizzlies were killed in the winter whenever one could be found in a den. Before an effort was made to kill the bear, the hunters used to defecate upon the earth dug from the den. They believed that doing so would ensure their finding a bear inside. For killing the bear, a triangular frame was prepared by binding together three heavy willow sticks, with a fourth placed from the base to the apex to give additional strength. The apex of this frame was inserted into the den mouth, and a certain phrase ("Nami kamma", meaning approximately "Is anything in?") was called out. The aroused bear would seize the wood and try to pull it into the den, and while thus occupied it was speared. These customs are no longer followed.

In timbered country bears were sometimes snared. A noose was placed above the trail, with the line running upward over a branch of a tree or through a hole in the tree itself. This line was attached to a very heavy log carefully balanced on end against the far side of the tree. When the bear pulled against the noose, the log was dislodged and its weight tightened the loop.

It is of interest that the Nunamiut have no knowledge of the brecding habits of the grizzly bear, and there is considerable speculation as to breeding time. An Eskimo named Tumaitchak, who was supposed to have killed more than 40 bears, observed a bear around the mouth of a den in December. The hunters went after this animal and killed it; it was found that it had just given birth to a cub. Twin cubs are the rule.

A. Muric (1944) has reported various observations on the relationship of wolves and grizzly bears. In the Brooks Range there appears to be frequent friction, resulting at times in actual combat. One of the Nunamiut, Kakinya, in the spring of 1939, came upon a bear and shot it. When he fired, three wolves, which he had not seen, ran out from nearby and escaped. Upon skinning the bear, he found it to have been severely bitten around the back and rump. It is not unusual for bears to drive wolves from their kills, but the bears seem to show fear of wolves. In early October 1950 I observed from the tracks that an adult bear sleeping in a creek bed high on a mountain side had been disturbed by a very large wolf. The bear left at a run and did not slow its pace until well down the mountain. Maptigak said that wolves often chase bears, and that bears always show fear of wolves. Arthur O'Connell, who has trapped for many years along the North Fork, stated that he has seen evidence of bear-wolf fights, and has found wolves killed by bears.

As far as can be judged from available information and personal observations, the numerical status of the arctic grizzly is good. Very old bears are not uncommon, indicating that these animals live, in general, unmolested. The Nunamiut do not recognize any decline in numbers, and in view of the relatively small region over which they hunt, they can have little effect upon the over-all bear population. It is unlikely that this animal will suffer a serious reduction in numbers unless they are subjected to considerable hunting by the white man. 
Ursus americanus Pallas ssp. Igakrik. Black bear.

The black bear rarely comes as far north as this region. I have not seen it farther north than Crevice Creek, which is several miles south of Hunt Fork. Frank Bishop, who has trapped along the John River for more than thirteen years, told me that the black bear occurs on Hunt Fork; he believed that it avoids the timbered country farther north where the grizzly bear is numerous. However, black bears are common along the south front of the Brooks Range, around the mouth of the John River valley and, on one day in September 1950, I saw 4 black bears between the mouth of the John River and Crevice Creek while flying north up the John River valley.

Only one specimen of black bear, a young male, has been secured from the Anaktuvuk Pass region. On 18 June 1951 it was killed by the Eskimo near the mouth of Inukpasukruk Creck. The length of this animal was 1,360 mm., and, as far as could be determined from its skull, when compared with skulls of captive bears of known age, it was about two years old.

The black bears are usually in their dens when the Nunamiut are in the timbered country, so there is little contact. The Eskimo are well acquainted with this species, and observe it from time to time, but know little about it. Maptigak reported having seen a wolf chase a full-grown black bear up a tree.

Vulpes fulva alascensis Merrian. Kayuktuk, fox; Kaviak, red fox; Kiangak, cross fox; Kiknyiktak, silver fox. Alaska red fox.

In the Brooks Range and over the Arctic Slope the red fox is one of the most common animals. Cross and silver colour phases are regularly seen. No information of particular interest has been obtained. I know of two cases where golden eagles have attacked red foxes without success. This has been reported also by Dixon (1933) and A. Murie (1944). In the main valley fox dens are found in knolls along the rivers. The Nunamiut name for fox den is sisrak.

The Nunamiut formerly used several methods for taking foxes. A snare, called kilusaktuk, was used to encircle the den mouth, but no one now living knows the details of its construction. A deadfall, called nanmautalik, was commonly used; it consisted of a platform of willow sticks loaded with stones. This was suspended from a bough of a willow tree by a single line so arranged that the platform fell when the line was cut. The line was fastened at the ground, and some fat was allowed to freeze on it. In attempting to chew off the frozen fat, the fox severed the line and was killed by the falling weight.

A more elaborate trap, used by the fathers of the men now living, was a sinew net called porgoh. This net, tied from caribou sinew, was about six feet wide, and was placed upright in a semicircle. Near the opening a small snow-house was built, just large enough to contain a man. A caribou carcass was placed inside the net, and the hunter would spend the entire night in the snow-house, watching through a small observation hole. When foxes or wolves came in to the bait the hunter would burst from the blind, and in their frantic efforts to run in the opposite direction, the animals became entangled and could be killed. The mesh of this net was large enough to catch the head 
of a wolf, but not so large as to allow foxes to escape. This trap was mentioned by Stefansson (1914, p. 388).

The isivrogak, consisting of a strip of baleen sharpened at both ends, coiled, and frozen inside a ball of blood, was formerly used by the Nunamiut for both foxes and wolves. The proper length of the isivrogak for foxes was equal to the distance from the middle of the palm of the hand to the end of the longest finger. Such baits were placed where they would be swallowed by foxes or wolves, and when the body heat had thawed the ball, the isivrogak sprang straight, penetrating the wall of the stomach and sooner or later causing death. This is a well-known Eskimo method, and has been discussed more fully by other writers.

The Nunamiut do not use fox fur themselves, but foxes are trapped for trade.

Eight fox skulls have been deposited in the U.S. National Museum. A large series is in cold storage. A total of 32 specimens from the Anaktuvuk Pass has been autopsied for parasites.

Alopex lagopus innuitus (Merriam). Tereganiak. Continental arctic fox.

The arctic fox is of irregular occurrence in the Brooks Range, but I have not yet sccured a single spccimen, though several reports of this animal have been obtained. Six werc killed just north of the mountains near Chandlcr Lake in 1936; 3 were killed on the Killik River in 1941; and one was killed on Easter (Agiagiak) Creek and another on April Creek, both tributaries of the Killik, in 1947. According to one report, aretic foxes may even cross the Brooks Range. David Tobuk, an Fskimo living in the village of Bettles, told me that an arctic fox was killed by an Indian on Henshaw Creek, about ten milcs south of Bettles, around 1910.

Perhaps such wanderings of the arctic fox occur during the times of high fox population following a periodic decline of lemmings on the Arctic Slope. The few records given here correspond closely to years following times of known high lemming density.

Canis lupus tundrarum Miller. Amaguk. Alaska tundra wolf.

Wolves occur commonly in the Brooks Range, but no observations of unusual interest have been made. The excellent report of A. Muric (1944), on the wolves of the Mt. McKinley region, contains the most complete information available on Alaskan wolves. The relationships of wolves to the other animals of the Brooks Range are no doubt very similar to those in the Mt. McKinley area.

Wolves have not often been observed in large packs in the Brooks Range, and are usually seen in groups of 3 to 6 . A pack of 15 animals was seen by the Eskimo during the winter of 1950. Paneak stated that a pack of 18 animals seen a few years back was the largest ever observed by him. In general, wolves are to be found wherever there are caribou.

There is much variation in wolf colour in this region. Grey or black are the common colour phases, and light-coloured animals are not often seen. Some few animals are relatively pale, but even in these the dorsal hairs are 


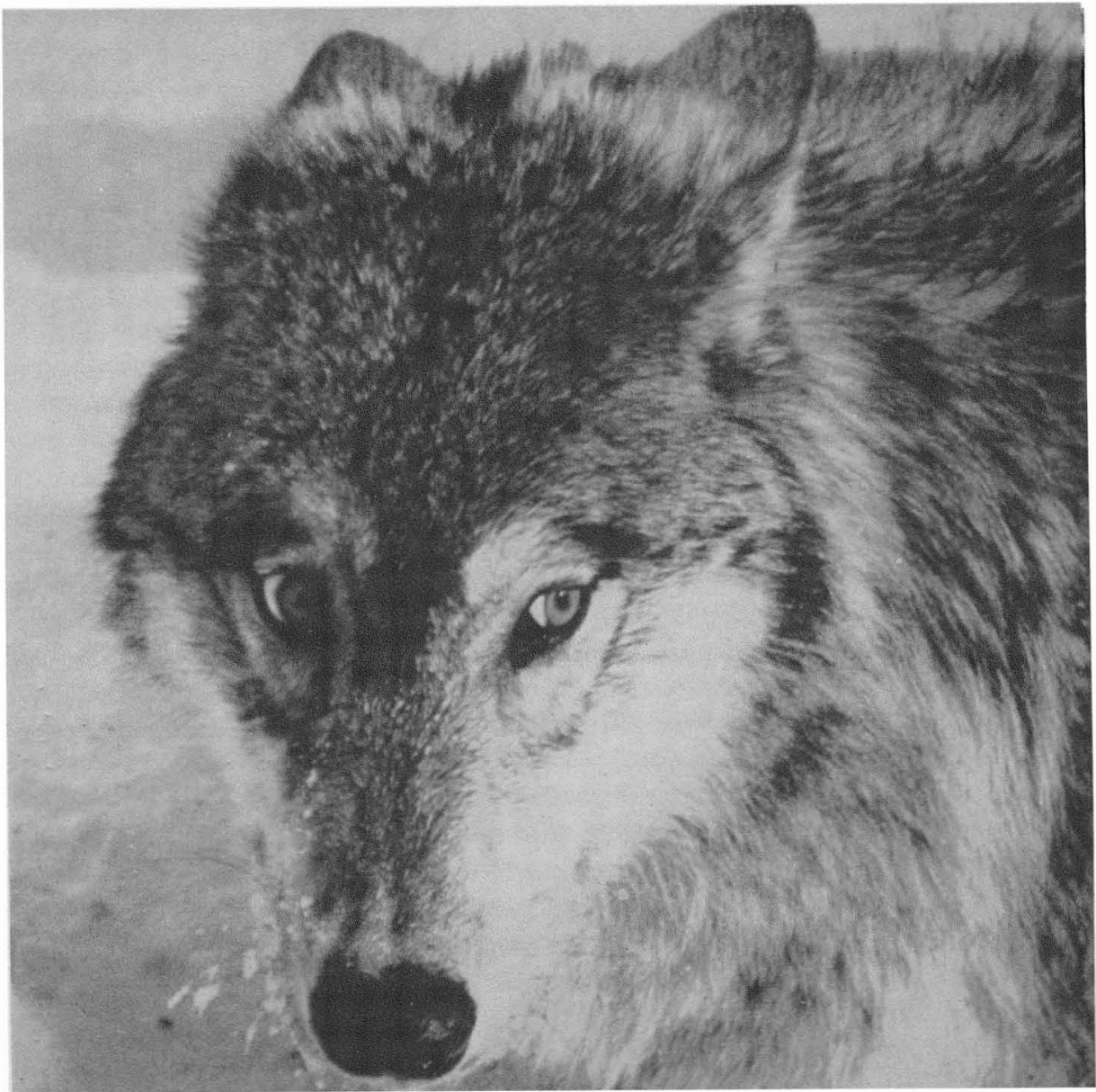

Fig. 13. Trapped wolf, Savioyok valley, April 1950.

heavily tipped with black. Rufous-coloured animals are occasionally seen, and I examined one skin which was heavily tinged with ochraceous-orange.

Wolves commonly den along stream banks, but dens are also found rather high in the mountains. One litter was removed from a limestone cave in the mountain just north of the mouth of Anaktiktoak Creek. Litters usually run from 3 to 6 cubs.

The tundra wolf is not exceptionally large. A few animals, killed conveniently near camp, were weighed (Table II). No effort was made to look for unusually large animals.

Rabies outbreaks in wolves have been known to occur in the Brooks Range, ${ }^{1}$ as well as in other parts of Alaska (McTaggart Cowan, 1949). The last of these was during the winter of $1944-5$, when rabid wolves occasionally

${ }^{1}$ This diagnosis is based on verbal descriptions only; however, properly diagnosed cases are known from other parts of Alaska, and I have personally obtained animals in which rabies was diagnosed on the basis of the mouse inoculation test. 


\section{THF, NUNAMIUT FSKIMO AND MAMMALS OF THE ANAK'TUVUK PASS REGION}

came into the Eskimo camps, where they were killed. An aged man, the father of Kakinya, was attacked by a rabid wolf and bitten on the hand. $\mathrm{He}$ succeeded in killing the animal, and suffered no ill effects from the bite. Dogs attacked by wolves in camp at night became rabid. A rabid wolf was seen pursuing another apparently normal wolf which, in its desire to escape, ran close to a hunter and was killed. The rabid wolf, showing no fear of man, came near and was also shot. This outbreak followed a year of high wolf density, according to the trapping success of the Nunamiut. The resulting decrease in numbers, however, was apparently not great. There are no reports of attacks on man by normal wolves.

\begin{tabular}{|c|c|}
\hline Sex & Weigh \\
\hline$\sigma^{x}$ & 55 \\
\hline$\sigma^{7}$ & 75 \\
\hline$\sigma^{7}$ & 78 \\
\hline $\begin{array}{l}0^{7} \\
0^{7}\end{array}$ & $\begin{array}{r}80 \\
106\end{array}$ \\
\hline \$ & 59 \\
\hline q & 63 \\
\hline
\end{tabular}

$\begin{array}{cc}\text { Sex } & \text { Weight } \\ \text { 9 } & 73 \\ + & 80 \\ + & 81 \\ + & 85 \\ 9 & 85 \\ 9 & 87 \\ 9 & 90 \\ 9 & 9\end{array}$

Table II. Weights of 14 wolves from the northern Brooks Range (in pounds).

The Nunamiut stated that wolves were rare in the Anaktuvuk Pass region from about 1911 to 1920 . During this time caribou were also scarce, perhaps as a result of their following migration routes which did not take them through this country. For the last few years wolves have been numerous; usually from 20 to 30 are trapped each winter, but more than 150 were killed in the winter of 1942-3. Forty-eight wolves were killed during the winter of 1949-50. They are occasionally shot during the summer and fall, but no effort is made to trap them in these seasons.

I have never seen a place with as many wolves as the Savioyok valley during the early winter of 1950-1. The Eskimo who went into this valley shortly before I did reported that they were unable to sleep the first night because of the noise made by the wolves howling, and their own dogs replying. It is interesting that the greatest density of mountain sheep and moose that I have seen in the Brooks Range was found in this valley, despite the relatively large wolf population.

A serics of 15 wolf skulls has been deposited in the U.S. National Museum. A larger series of skulls, as yet unprepared, is in cold storage.

Martes americana ?actuosa (Osgood). Kaviatchiak ("new wolverine"). Alaska marten.

The marten is rare in the Anaktuvuk Pass region, and only one specimen, from Hunt lork, was obtained. This animal was trapped by an Eskimo during the winter of 1948 . According to Frank Bishop, marten do not occur far up the John River valley. It is possible that they are more abundant on the North Fork drainage where only a limited amount of field work was done. Marten tracks were observed in the Savioyok valley in the winter of 1949-50.

The single marten obtained differs considerably from any specimen in the mammal collections at the U.S. National Museum. The ochraceous colouring 
is limited to the posterior third of the dorsal part of the body. The head is very pale grey, with a slightly darker median streak which gradually darkens and extends the full length of the body. No throat patch is present, and the entire throat is grayish buff. The fore feet and legs are nearly black, and the hind feet and legs are very dark with a light area on the front of the leg just above the foot. The tail is mostly dark, with some orange-tinted hairs interspersed. The dorso-posterior third of the body is bright orange, similar to Ridgway's Ochraceous Orange. This animal, a male, weighed 1,050 grams. The cranial differences do not seem significant on the basis of a single specimen.

According to the Nunamiut, ptarmigan and mice form the main diet of the marten in this region, but no personal observations were made.

Mustela erminea arctica (Merriam). Iteriak (from iteriaktuk, "to get up early"). Ermine.

Ermine are common in the region, presumably because of the favourable habitat and abundance of voles. Twelve skins and skulls were deposited in the U.S. National Museum in 1949-50, a series of similar size is now in cold storage, and others have been autopsied for parasites. The Nunamiut usually trap 40 or 50 of these weasels each year.

The ermine apparently does not range very high on the mountain sides, but its tracks are found up most tributaries of the Anaktuvuk and John rivers. Tracks are frequently seen around wolf-kills and around deadfalls set for wolverine. Dens are found among rocks in favourable places, or in knolls along the rivers. The ermine does not seem to have many enemies in this region. The golden eagle and gyrfalcon may kill a few, but the snowy owl, its main predator on the Arctic Slope, is uncommon here.

The molt into winter pelage takes place in late September and in October. There is no uniformity in this, and individuals ranging in colour from that of summer pelage to nearly pure white may be caught within a few days' time.

Mustela rixosa rixosa (Bangs). Naulayuk. Least weasel.

Although widely distributed and well known to the Nunamiut, the least weasel is rarely seen, but tracks are occasionally found around vole burrows and along the creeks in winter.

Four specimens so far obtained were taken more or less by accident in mouse traps. Three of these were in winter pelage, and one, caught in late May, was in summer pelage. A male animal collected 20 March 1951 did not show any beginning of molt into summer pelage. The weights and measurements of the animals are as follows:

\begin{tabular}{|c|c|c|c|c|}
\hline Sex & Weight & Total length & Tail & Hind foot \\
\hline tit & 51.0 grams & $177 \mathrm{~mm}$. & $19 \mathrm{mmm}$. & $24.5 \mathrm{~mm} 11$ \\
\hline s & 31.4 & 170 & 19 & 24 \\
\hline q & 28.0 & 149 & 10 & 17 \\
\hline 우 & 26.0 & 155 & 17 & 22 \\
\hline
\end{tabular}

Mustela vison Schreber ssp. Iteriakpuk ("big weasel"). Mink.

The mink is rare and is perhaps never resident in the Anaktuvuk and upper John River valleys. Tracks at Chandler Lake and along Hunt Fork were 
reported by the Nunamiut. I saw tracks in the upper Savioyok valley in the fall of 1950 , and it is possible that mink are permanent residents in this valley as the creeks are kept open all winter by flowing springs. The invertebrate fauna of these creeks is abundant, and a small arctic char, Salvelinus alpinus (L.), is common. No specimen of mink has been obtained.

Gulo luscus luscus (Linnaeus). Kavik. Wolverine.

The wolverine is widely distributed in this region. Eight skulls have been obtained; their measurements are given in Table III.

$\begin{array}{ccccccc}\text { Sex } & \begin{array}{c}\text { Condylobasal } \\ \text { length }\end{array} & \begin{array}{c}\text { Zygomatic } \\ \text { width }\end{array} & \begin{array}{c}\text { Squamosal } \\ \text { constriction }\end{array} & \begin{array}{c}\text { Coronoid } \\ \text { height }\end{array} & \begin{array}{c}\text { Maxillary } \\ \text { tooth row } \\ \text { length }\end{array} & \begin{array}{c}\text { Interorbital } \\ \text { width }\end{array} \\ \text { Oे }^{7} & 140.7 & 101.2 & 77 & 50.5 & 51.3 & 38.6 \\ \sigma^{7} & 141.6 & 101 & 78 & 48.7 & 51.9 & 38.6 \\ \sigma^{5} & 143.7 & 105.1 & 80.6 & 50.5 & 52 & 43.4 \\ \sigma^{7} & 144.5 & 103.4 & 80.7 & 51.2 & 51.5 & 42.6 \\ \sigma^{7} & 145.5 & 104 & 76 & 52 & 54 & 39 \\ \sigma^{7} & 146 & 106 & 77.5 & 52.5 & 54 & 41 \\ ? & 147.5 & 107.5 & 76.1 & 50 & 54.9 & 42.5 \\ \sigma^{7} & 155.5 & 111 & 86 & 53.5 & 57 & 41\end{array}$

Table III. Skull measurements from 8 wolverine collected in the Anaktuvuk Pass region (in millimetres).

Degerb 61 and Freuchen (1935) were of the opinion that the North American and European wolverines belong to the same species. This conclusion does not appear to have had the support of American mammalogists. However, in view of the ever-increasing number of species now recognized to have a circumpolar distribution, it would seem that the wolverine will likewise have to be considered a circumpolar species. I have not compared the skulls of Brooks Range wolverines with those from Eurasian animals.

A large male wolverine, trapped 20 October 1950 at the mouth of Anaktiktoak Creek, measured $925 \mathrm{~mm}$. in total length and weighed 34 pounds. The Nunamiut remarked that they had never seen any larger than this.

The Eskimo maintain that the male animals are most often dark-coloured, while the females show prominent lateral streaks. On the basis of a relatively small number of skins examined, this appears to be the case. There is much colour variation; the lateral streaks vary from nearly white to rufous or brown, and in some males are hardly visible.

The food of the wolverine consists mainly of snowshoe hares, a good proportion of mice, and occasional wolf-kills and other carcasses. Under favourable conditions a few sheep are killed, or, rarely, a caribou.

From 3 to 6 wolverine are trapped each year by the Nunamiut, who use the fur for parka trimming. In some years as many as 12 to 15 are killed. I have not heard of any case of wolverine robbing caches in this country; this is probably because of their general scarcity. The Nunamiut ordinarily trap wolverine in rock deadfalls. These are set in the fall, using as bait the nose or foot of caribou, which cannot readily be destroyed by voles. The site is selected with considerable care, so that the deadfall will not be covered by snow. Many such traps can be set, and it is not necessary to check them until 
spring since any animals caught remain frozen and in good condition. A spruce deadfall, called namugotalik, is used in the timbered country. This is made of spruce trunks loaded with rocks and a spruce trigger with a length equal to that of a man's arm from the axilla to the base of the hand.

None of the Nunamiut has seen a wolverine den, nor do they know anything of the animal's breeding habits. Inyualuruk reported that in the spring a wolverine, with two small young, was killed in a den in the snow near the north edge of the mountains.

Lutra canadensis (Schreber) ssp. Panioktuk ("big tail"). Otter.

It is doubtful if any otter are resident in this region. Tracks are seen at times along Hunt Fork, and one animal was seen at Kanayut Lake in 1950. No specimen has been obtained. The Nunamiut know the otter, although few of them have seen it. It is possible that otter visit the Savioyok valley from time to time, but here also they must be of only casual occurrence.

Lynx canadensis canadensis Kerr. Niutuyik ("long legs"). Canada lynx.

The lynx occurs in the timbered sections of the region, and in some years may be found far to the north of the last spruce timber. Such variable occurrence is, of course, closely connected with the abundance of snowshoc hares. I have obtained a specimen from as far north as the mouth of Publatuk Creek, near the last spruce timber, and another from Hunt Fork, where tracks were common during 1949-50. Both specimens have been deposited in the U.S. National Museum. Lynx tracks were abundant in the Savioyok valley during the winters of 1949-50 and 1950-1, but no specimen was obtained. The Fskimo recall having seen lynx as far north as Tulugak Lake in the winter of 1916 or 1917.

The Nunamiut snare an average of about 5 or 6 lynx a year, but no particular effort is made unless fur prices are high.

Lepus americanus dalli (Merriam). Ugalik. Snowshoe hare.

The snowshoe hare ranges as far north as Kalutak Creek, where it is found in the willows along the main valley. It is, however, much more common in the timbered country to the south and east. Although only 4 skins and skulls have been deposited in the U.S. National Museum, a large series has been autopsied for endoparasites.

According to the Eskimo, the hare population does not show marked fluctuations in this region. This has been substantiated by Frank Bishop, who stated that the last hare "high" in the country around the mouth of John River took place during 1946. The lynx decreased soon after this time, and I obtained a nearly starved lynx near the village of Bettles as late as the fall of 1949. Bishop also observed a heavy mortality in willow ptarmigan during 1945.

Snowshoe hares are easily taken during the winter months, but I have not yet obtained a specimen in summer pelage, so subspecific determination should remain tentative for this form. A young animal not completely molted into winter pelage was taken in a wolf trap in the Savioyok valley during late 
October 1950. It was so badly damaged, however, that it was not retained.

The Nunamiut capture hares by sinew snares during the winter, but since relatively few are obtained they are of little importance in the dict of the people.

Lepus othus othus Merriam. Ugalishugruk. Arctic hare.

It is possible that the arctic hare may occasionally be found near the northern limit of the Brooks Range, although little information is available. The Nunamiut reported having seen this hare near Umiat on the Colville River and near the mouth of the Anaktuvuk. The Killik people formerly travelled in this region, but have not done so in recent years. In a letter quoted by Howell (1936 a, p. 334), Charles D. Brower writes: "Several times I have had these large hare skins brought into Barrow by natives wintering up the Colville River". I have made a number of flights by small aircraft over this country just before snowfall, but sufficiently late in the year for the hares to be white and easily visible, but I have yct to sce one.

Marmota caligata broweri Hall and Gilmore. Sikrikpuk. Hoary marmot.

Until the present material was obtained, this hoary marmot was known only from Point Lay and Cape Thompson (Hall and Gilmore, 1934). Scattered colonies occur commonly in the Brooks Range, and it is often locally abundant. There is one colony about ten miles south of Tulugak Lake, and others are found near Anaktuvuk Pass. The Nunamiut say that it is common near the head of the Killik, also that marmots are found among some sandstone cliffs from thirty to thirty-five miles north of Tulugak Lakc.

Marmots from northern Alaska have been mentioned in the papers of Bailey and Hendee (1926) and Hall (1929). Anderson (1934) published a map of North American hoary marmot distribution, but at that time had no information on the Brooks Range form. I have so far obtained 8 skins and skulls of this species from Anaktuvuk Pass, in addition to 7 skins only. The skin and skull of an adult marmot of this species were obtained near Arctic Villagc, on the Chandalar River, and I have examined skins typical of this form from Big Squaw Lake, farther south near the village of Chandalar. Although considerable effort was made to obtain marmot specimens in the Romanzof Mountains, near Lake Schrader and Lake Peters, I was unsuccessful. It is nevertheless clear that $M$. caligata broweri is the form found throughout the Brooks Range, probably as far as the Alaska-Canada boundary.

Brooks Range marmots enter the dens for the winter not later than the middle of September. The exact time of emergence in the spring is not known, but as late as 21 May 1950 marmot dens were still snowed in, so it would seem that emergence must take place in June. By this month much vegetation is already available for food, particularly saxifrage. Saxifraga bronchialis Funstonii (Small) Hult. and Pyrola grandiflora Radius are important as food. Therofon Richardsonii is eaten, as are lupine and various other legumes.

Dens may often be seen from a great distance as the surrounding vegetation is more brown and the nearby rocks may be orange from the brightly- 
coloured lichen, Caloplaca granulosa (Müll. Arg.) Steiner. This lichen is a strongly nitrophilous species, which flourishes where there is marmot urine, It is also frequently seen around bird rocks. Marmot dens may be found in both limestone and conglomerate rock, and there is usually a nearby source of water.

The most important predator on the marmot in the Brooks Range is the golden eagle, which occurs in good numbers. The fox may be second in importance.

The Nunamiut trap marmots by rock deadfalls. The skins are sold for making parkas, and the carcasses are eaten. Marmots are a particularly useful source of food as they are available in the summer when caribou are often few or entirely absent.

Citellus parryii barrowensis (Merriam). Sikrik. Parry ground squirrel.

The ground squirrel is one of the most abundant and conspicuous of the Brooks Range mammals. It is found in a variety of habitats, from sandy river banks to high mountain sides, wherever the vegetation is low or sparse, and occurs in most of the previously mentioned plant communities which grow on drier ground. It is common on the mountains to at least 3,500 feet, in rocky areas grown to Cassiope and lichens.

Hibernation usually begins in late September or early October, and tracks are not uncommonly seen in the first snows of fall. In 1949 I saw squirrels on September 22, 28, and 29, and in 1950 on September 28 and October 3. They were scarce in September 1951, probably remaining in their burrows during the unusually poor weather of this month. Activity outside the burrow is intermittent and depends upon very favourable weather and sunlight.

The squirrels emerge from hibernation very early, about March 25 to April 15, when the only evidence of the coming spring is the increasingly longer period of daylight. By the latter part of April their presence is evident from tracks in the snow on bright, sunny days. On dark and windy days they remain inside the burrows, which are repeatedly filled with snow by the storms of early spring. Their early spring activity is interesting; they often emerge from a burrow and take a dircct course across the snow for as much as fifty yards, where they dig down to the mouth of another burrow. The reason for this behaviour is not apparent, but they seem to leave one burrow for another, since returning tracks are rarely seen. Possibly at this time the males are seeking females.

In the early spring the squirrels feed largely on willow, as indicated by stomach contents. Later their diet is made up from a variety of plant species.

Breeding appears to take place in late April or early May, and the male animals are first to emerge from hibernation, according to the specimens examined. By the last part of May the females have well-developed embryos in the uterus. By early July the young animals are well grown, and by midJuly weigh around 360 to 380 grams.

Thirty-eight squirrels were collected in 1949; 16 in 1950, and only 9 in 1951. Most of these were autopsied only. Eight skins and skulls were 
deposited in the U.S. National Museum in 1949 and additional specimens have since been prepared.

The total length as given by Hall (1929) is large for the Brooks Range specimens. Male animals, collected in early May, measured from 370 to 380 mm., and females from 340 to $352 \mathrm{~mm}$. For males, the tail length ranged from 97 to $101 \mathrm{~mm}$., and the foot length from 54 to $63 \mathrm{~mm}$. Nine male animals, collected from 4 May to 6 May 1949, weighed from 530 to 977 grams (av. 653 grams). Weight, of course, depends upon season, and the heaviest animals are obtained just before hibernation.

When caribou are scarce the Nunamiut sometimes kill ground squirrels for food. They are taken by snares, and, in recent years, by steel traps. Farlier custom required that a period of time had to elapse after squirrel had been cooked before the pot could be used for any other meat.

Tamiasciurus hudsonicus preblei Howell. Sakalatayik. Mackenzie red squirrel.

The red squirrel does not extend beyond the northern limit of spruce timber. Seventy-six specimens were obtained in 1950 from the last timber on the John River and from the Savioyols valley. Four specimens were deposited in the U.S. National Museum in 1949; a larger series is waiting to be deposited, and more than 20 are in cold storage. No specimen has been obtained in summer pelage as practically all summer field work has been north of timber. The Brooks Range red squirrel reaches a total length of as much as $376 \mathrm{~mm}$. Six adult females, taken in March, averaged 229 grams in weight, and 6 adult males, taken at the same time, averaged 258 grams. This is obviously a larger animal than the specimens upon which the subspecies preblei is based (Howell, 1936b). It is possible that further study will show that this squirrel represents a distinct form.

In the Savioyok valley, red squirrels ranging in colour from an unusual pure ochraceous colour to the normal colour have been taken. The palest animal had only a few dark hairs along the lateral streaks and on the front legs, the face, and margins of the tail.

In general habits, this animal does not differ from the same species farther south. To my knowledge the Nunamiut do not make any use of the red squirrel.

Lemmus trimucronatus alascensis Merriam. Avingak. Alaska brown lemming.

The status of the brown lemming in the Brooks Range is difficult to determine. I have secured a few specimens south of Tulugak Lake, but it has been uncommon during the time of this work.

On 6 May 1949, when the spring thaw was just becoming evident, I saw a brown lemming on a small snow-free area near Tulugak Lake. On July 12 the first specimen, an immature animal weighing 20 grams, was trapped in "niggerhead" tundra in the main valley, just east of Tulugak Lake. From September 12 to September 26, however, 14 wcre obtained in the area of the flowing springs near the lake. These September specimens weighed from 18 to 
35 grams (average about 25 grams); no adults were taken. In the Savioyok valley 3 adult animals were taken on 15, 16, and 17 December 1950 . None otherwise has been obtained from the timbered sections of the region.

No special effort was made to trap lemmings and all specimens were taken during general trapping for small mammals. As mentioned elsewhere (Rausch, 1950a), brown lemmings were most readily taken in unbaited runway sets.

The Nunamiut, who are familiar with the population fluctuations of the brown lemming along the Arctic Coast (see Rausch, 1950a) stated that they had never known a high population density in the Brooks Range. During the summer of 1951, this species was abundant in the Romanzof Mountains near Iake Schrader and I ake Peters, and a good scries was collected.

Dicrostonyx groenlandicus rubricalus (Richardson). Kilakmiutak ("sky" animal"). Alaska varying lemming.

The varying lemming is well known to the Inland People, who share the common Eskimo legend that the white lemming falls with the snow from the sky. I have seldom seen this animal south of the divide between the rivers, but the Eskimo stated that they had seen tracks as far south as Hunt Fork. This lemming of ten occurs high in the mountains, and 1 have seen its characteristic tracks in the pass leading down into the Savioyok valley. These animals travel for great distances on the snow surface; this behaviour has been noted by Degerbol and Freuchen $(1935$, p. 88$)$ and other writers.

A total of 5 specimens was obtained in 1949; 7 in 1950, and $t$ in 1951 . Tracks were secn occasionally, but the animal could not be considered common. No specimens were taken in traps; all were captured by hand on the tundra.

The molt into summer pelage takes place during late April and early May, bit the time it is complete is not known. In the fall, the molt occurs mainly during September. A specimen collected on 24 September 1949 showed some white hairs in the coat, but the head was still dark and the dorsal stripe was distinct; the snow claws were beginning, to grow. A specimen obtained on 25 September 1950 was white except for the ears; another collected on 9 October 1950 was quite pale, but still showed traces of the summer pelage; and one taken on 18 October 1950 showed a slight grey tinge. It is evident that the molt takes place much carlicr in the spring and much later in the fall than it does on the Arctic Coast.

Very little was observed on the breeding of this animal. A captive female gave birth to 6 young on 27 April 1949. A nest containing + young was discovered in a short burrow on 17 July 1951 ar Lake Schrader.

A few observations were made on the feeding habits of the varying jemming. One animal had a leaf of Ledum in its mouth when it was captured, and another had a leaf of Dryas integrifolia. An animal captured on 25 September 1950 was carrying moss, Rbytidium rugosum, into its burrow, presumably for a nest.

According to the Nunamiut the varying lemming never becomes abundant in this region. This species was rather numerous in the Romanzof Mountains during the summer of 1951 and a series was collected there. 
Clethrionomys rutilus dawsoni (Merriam). Avingak. Red-backed vole.

The red-backed vole was the second most common mouse-like rodent in this region. It was trapped most often in the lower country, particularly in the main valley, but it was also taken at altitudes up to 3,000 feet. This vole was found in a variety of habitats, but apparently preferred Salix and SalixBetula nana communities where the ground was covered with dense moss. I collected a few specimens at Umiat on a dry slope heavily grown to Salix spp. and Alnus crispa, above a dense growth of mosses and lichens.

The burrows of the red-backed vole were common in moss hummocks around the base of willows, particularly in the spring-area at Tulugak Lake. Small round burrows were found among limestone talus overgrown with Cassiope, near the top of a low mountain at an altitude of more than 3,500 feet. Characteristic fecal deposits were noted at the entrance to the burrows.

In the winter, tracks showed that this vole fed on wolf-kills and other available carcasses, but no other observations were made on their feeding habits.

Red-backed voles were readily trapped in the winter, in contrast to the other species of microtine rodents in this region which, with the exception of Dicrostonyx, remain under the snow.

As is characteristic of voles of the genus Cletbrionomys, the Brooks Range specimens show much variation in colour, ranging from a buffy-brown to a striking ochraceous-orange. Part of this variation is, of course, seasonal, but in general colour has little taxonomic value in this group (see Rausch, 1950b). The maximum weight of this animal rarely exceeds 30 grams.

More than 100 specimens have been collected from the Anaktuvuk Pass region, but relatively little information was obtained on breeding habits. Breeding apparently begins in May and has stopped by early September. More than 70 animals have been collected in the Savioyok valley, and a few at Uniat. One specimen was taken during July 1951 at the south end of Lake Schrader in the Romanzof Mountains, and a series was obtained at Aretic Village.

Microtus oeconomus macfarlani Merrian. Avingak. Tundra vole.

The tundra vole has been relatively uncommon during the time of these observations, and only 65 animals have been obtained. The majority was taken near the spring-area of Tulugak Lake, but a fair series in winter pelage was trapped during the fall of 1950 , just south of the divide. Two specimens were taken in the timbered Savioyok valley; one was taken on the tundra just north of the mountains, and a few were found frozen in an Eskimo cache on the Killik River. The tundra vole is distributed over much of arctic Alaska ${ }^{1}$. A few specimens were obtained at Umiat and at Bettles, near the mouth of John River; 5 were taken at Lake Schrader during July 1951, and a good series was collected at Arctic Village. Hall (1929) reported this species from a river, possibly the Meade, about fifty miles south of Barrow.

During these observations the tundra vole appears to have occurred in restricted colonies only. It prefers areas grown to sedge (Carex spp.), or various grasses. One specimen was taken in a Carex aquatilis-C. Bigelowii

${ }^{1} \overline{W e}$ have also collected large series from regions south of the Brooks Range. 
community, and several were taken in a dry area grown to a dense stand of Calamogrostis inexpansa A. Gray near Tulugak Lake, where there were many typical Microtus runways, with characteristic cuttings.

This vole seems to take readily to the water. One entered a small pond west of Tulugak Lake, in the main valley, and was shot as it surfaced and swam toward the middle of the pond, which was grown around the edges to Arctopbila fulva (Trin.) and various sedges. The Umiat specimens were also taken in a sedge community along a small lake. Voles of the genus Microtus have been reported to swin readily by various authors (Blair, 1939; Hatt, 1930).

Microtus oeconomus seems much more restricted in its habitat than is M. miturus, discussed below. Gilmore $(1946$, p. +1$)$ considered M. kamtschaticus ( $M$. oeconomus) a dominant form, and stated that: "This ultimate glacial ..., and post-glacial spread of $M$. kantschaticus pushed $M$. miturus into isolated mountains or peripheral localities." $M$. miutus was very abundant in the Brooks Range during the time observations were made, and occurred in a great variety of habitats at all altitudes, while $M$. oeconomus was not common and occurred in restricted habitats on the floor of the main valley. It would seem that $M$. miurus is more restricted by factors connected with altitude and latitude than by competition with $M$. oeconomus.

According to the observations of Quay (1951), a closely-related form, M. oeconomis operarius (Nelson), was found to prefer very wet areas on the Seward Peninsula. The Brooks Range animals did not show a marked preference for any one habitat, but appeared to be restricted by altitude. Observations over much of the Territory indicate that both subspecies are found in a variety of habitats. During the time of these observations, breeding was restricted to the summer.

Microtus miurus paneaki Rausch. Avingak. Narrow-skulled vole.

This vole was the most abundant microtine rodent of the region throughout the observations, but a definite decline in its numbers was noted by September 1951. More than 300 were obtained, although no effort was made to collect large numbers. The first specimen taken, on an evening in eariy June 1949, jumped into a small creek and swam for some distance beneath the surface. These voles never hesitated to enter the watcr in an attempt to escape.

In the Brooks Range narrow-skulled voles were commonly found to an altitude of 3,500 feet and more, and their well-worn runways were often seen on the mountain sides, but preference was shown for wet areas. They were frequently collected on the floor of the main valley. Specimens were trapped in all possible habitats, with the exception of Cassiope-lichen communities above an altitude of about 4,000 feet, and Carex communities beyond the mountains. Although this species is found around Umiat (Rausch, 1950b), it is not known whether it exists on the open tundra away from the hills, which here reach an altitude of slightly over 900 feet. It would also be of much interest to know whether this vole occurs north of the Colville River. A good series was obtained at Arctic Village and at Lake Schrader, in the Romanzof Mountains, during 1951. 
Microtus miurus was seen in isolated colonies in some places where favourable habitat was limited. Seepage areas on the mountain sides, grown to Therofon Richardsonii and Cassiope tetragona with a dense cover of Rhytidium rugosum, though usually quite small in area, often supported a large population. One of the largest colonies occurred in and around a semi-submerged sedgebog, with the nest burrows in nearby solifluction terraces. Clear-cut runways were not always developed, but were seen best in wet lowlands grown to sedge, on solifluction tcraces, and on dry, rocky, Dryas-covered slopes.

Runways were seen to extend for considerable distances on the mountain sides. On one south-facing slope, at an altitude of about 2,500 feet, a single, well-worn runway ascended from a creek bed for a distance of fifty-six metres. At its highest point it branched, one branch running east along a solifluction terrace for a further fifty metres, while the other branch ran perpendicular to it for about twenty metres. The main burrows of the voles were in the terrace and in the creek bank. However, thirty-one holes or groups of holes, from one to three metres apart, were found along the main runway up the mountain.

Burrows were numerous, and in the main valley were usually marked by little heaps of evenly-granulated black earth at the openings. Earth expulsion seemed to depend partly on the character of the soil, and was greatest in the late summer when storage chambers were being excavated in small mosscovered hummocks. Excavation of this type has been described by Rand (1945) for $M$. andersoni. M. miurus stores the rhizomes of Carex spp. and other plants in these chambers for winter use. A typical chamber measured $30 \times 20 \times 10 \mathrm{~cm}$., and contained 1,367 rhizomes weighing 820 grams. These roots were not identified; however, Carex aquatilis and C. Bigelowii were abundant nearby. The Nunamiut at times search out such stores for their own use, and caribou may also tear them open with their feet to eat the contents. I found that $\dot{M}$. miurus at Lake Schrader cached large stores of Polygomum vivipartm roots; they also dried piles of willow twigs for storage, but I never observed this behaviour in the Anaktuvuk Pass region during three summers' work. Rand (1945) reported that rhizomes of C. scirpoidea werc stored by $M$. andersoni.

Reproduction began in May and ceased by September 1. The males showed a definite testicular regression by early September. The young number usually from 4 to 8 , with an average of 6 .

During the spring of 1950 short-eared owls were particularly numerous in areas where this vole was abundant. These were probably migrant birds, since no nests were observed. As mentioned earlier, this vole is often dug out by the arctic grizzly, and is also preyed upon by foxes and weasels.

Four specimens were trapped in the Savioyok valley during October 1950. This vole does not seem to extend far into the timbered country; but the southern limits of its distribution have not yet been determined.

From his observations on a closely-related form, M. miurus oreas Osgood, on the Seward Peninsula, Quay (1951) concluded that: "This vole was less generally distributed than oeconomns and seemed to have more critical habitat 
requirements. It appearcd to avoid the wet areas where standing water was present at the surface, and where oeconomus was indigenous." As may be scen from the discussion of the habitat of the Brooks Range species, these forms do not secm to agree closely in their habitat requirements. However, such things may be intimately related to population dynamics.

Castor canadensis canadensis Kuhl. Paaluktuk. Canada beaver.

Trees cut by beaver in the Savioyok valley are the only evidence of this animal in the region. As far as could be determined from personal observation and information from the Nunamiut, none exists there now. It is possible, however, that they occur some miles farther south in the same valley.

One of the Fskimo, Pilala, reported having found a beaver dam, less thain ten years old, in the last timber on the creek leading into Asinak Lake (Loon Lake) in the winter of 1950.

Erethizon dorsatum myops Merrian. Kingragaluk (from kingak, "nose"). Alaska porcupinc.

The porcupine occurs irregularly to the limits of spruce timber, and some ycars is found much farther north. One was killed by the Eskimo at Chandler lake in 1943, and another in 1946. Two animals were killed on Kalutagiali Crcek in 1948. One specimen was secured from upper Hunt Fork and the skull has been deposited in the U.S. National Muscum. Evidence that porcupines have been feeding and the occasional finding of quills show that these animals occur in the Savioyok valley, but so far none has been seen.

Alces americana gigas Miller. Tutuvuk ("big caribou"). Alaska moose.

In the main valley as far north as Anaktuvuk Pass, the moose occurs sporadically, and some are seen each year. However, this animal is commonly seen in the lower John River valley and apparently there is a yearly northward movement along the main valley. The Nunamiut statcd that moose also move to the north through the valleys of the Chandalar and the Kuparuk. Moose have been known at Umiat for a long time, and in the summer are found as far north as the mouth of the Colviile. In the winter, however, they are rarely found beyond the mouth of the Anaktuvuk. Anderson (1924) discussed the northward extension of the moose in Canada. According to the Nunamiut, however, moose have long been known along the Colville, since their fathers and grandfathers hunted them there, and their occurrence in this region does not represent a recent extension of their range.

Although the numbers are perhaps too small to have any significance, it is of interest that most of the moose passing through the main valley to the north are young-usually about three years old. Four animals were seen in 1950 , and this is about the usual number.

Moose were abundant in the Savioyok valley in the fall of 1950 , where they were observed in herds up to 20 in number, just following the rut. The Eskimo had not hunted there for at least thirty years, and the animals were not accustomed to man. During Septcmber, when a few animals were killed for food, bulls were attracted to the spot solely by the sound of the rifle. A bull 
was killed which had sustained a completely pierced antler in the fighting which accompanied the rut. An enormous amount of force must have been required to drive a tine through the matured palm of a large bull.

In the main valley the browse supply is sufficient to maintain a large moose population. In the Savioyok valley, where moose are particularly abundant, the effect of their browsing is cvident everywhere. However, the vegetation has not yet been seriously damaged. In this valley a trail worn to a depth of more than three feet leads to a moose-lick. According to the Nunamiut, there is also a well-worn lick in the Killick vallcy, where moose occur in good numbers.

Wolves are abundant in the Savioyok valley, but predation is certainly not detrimental to the welfare of the large moose population. I have seen oniy one carcass, that of an adult bull. Although it had been eaten by the wolves, the cause of death was not evident. If the moose were not checked in somc way, there is no doubt that the browse supply would be severely damaged, with a resulting reduction in moose numbers.

The Nunamiut migrate to moose country only when caribou are few, and the people are forced to kill moose in order to survive. They prefer not to live on moose meat for long periods, and I have found from personal experience that it is not nearly as satisfactory as caribou. Since most of this country is not convenient cnough for sport hunting and much of it is closed by law to hunting by the white man, it would seem that the animals here should thrive as far as habitat conditions will allow and predation and disease must be depended upon for control. A. Murie (1944) has made the only wellsubstantiated observations on wolf-moose rclationships in Alaska.

In former years moose were snared by the Fskimo. For this purpose, a line of twisted caribou hide about an inch in diameter was used.

The Nunamiut names for animals of various ages are of interest, and indicate a long familiarity with the species. Ccrtain of these names are included here:

Nogak-calf.

Angayukliakruk-yearling.

Kiklisiksralik-young of ("with horn big enough for handle of flint sharpener").

Katnautalik-2-year-old is ("having fork at tip of antler").

Atkatiksralik-3-year-old to ("having antler palm shaped likc mirten"). Puknik-old bull.

Kulavak-cow.

A single moose skull from Anakturuk Pass has been deposited in the U.S. National Museum.

Rangifer areticus stonei Allen. Tutu. Stone caribou.

The caribou is one of the most frequently seen mammals of the Brooks Range country, and is the most important animal in the economy of the Nunamiut. Because of its migratory habits and the lack of accurate obscrvations, its numerical status is highly conjectural.

The migrations of the caribou in the central Brooks Range and on the adjacent Arctic Slope are very complex, and a large number of well-integrated 
observations will be required before they are understood. The general pattern of migration through the central Brooks Range, as derived from personal observation and that of the Nunamiut, is shown in Fig. 14. There is no

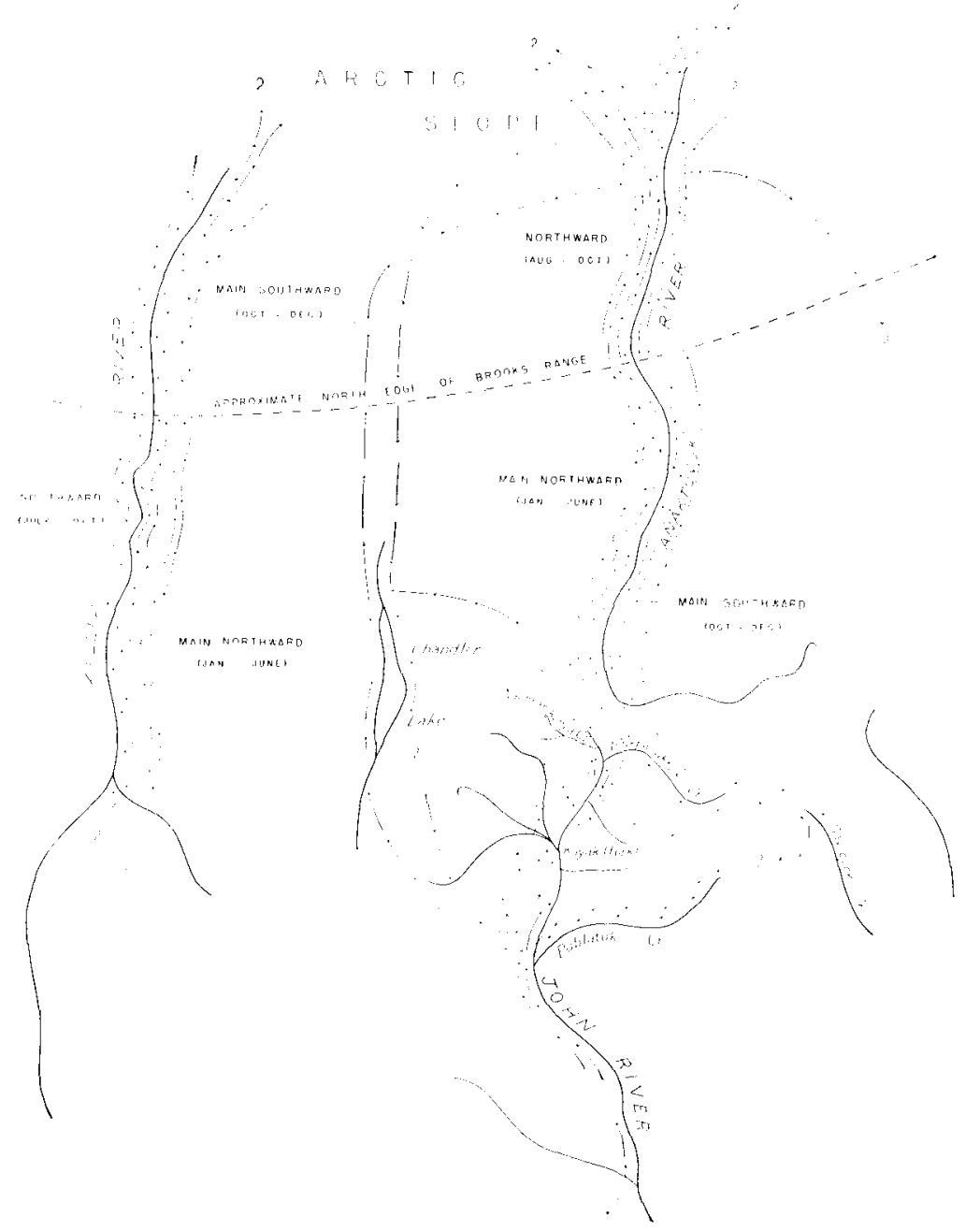

lig. 14. Diagram showing the main routes of caribou migration in the Anakturuk Pass region. Other routes are used irregularly.

information, however, regarding migrations to the south and to the east, and relatively little for the Arctic Slope. Caribou movement is very erratic-a highly important factor, since the route taken may determine their exposure to hunting pressure.

In the Anaktuvuk Pass region a northward movement of caribou usually becomes apparent in January, continuing until June. The herds vary in size, from only a few animals to thousands, and movement is continually northward through the main valley. The first animals to appear are the cows accompanied by calves of the previous year. Young bulls are next in sequence, and 
the old bulls, with an admixture of younger ones, come last. By April 1 the cows have ordinarily passed through to the Arctic Slope, where the calves are born.

From early June until mid-summer, caribou are usually absent from the main valley, but in early August (August 9 in 1949) a second northward migration may be seen. The herds are of mixed sex and age and are variable in size, but the majority number less than 200 animals. Fcw observations on herd composition were made; the following examples, however, are representative:

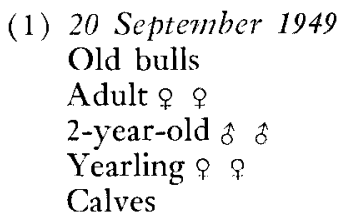

Total
(2) 20 September 1949 Old bulls

Adult $q$ ?

Yearlings

Calves

(3) 23 September 1949

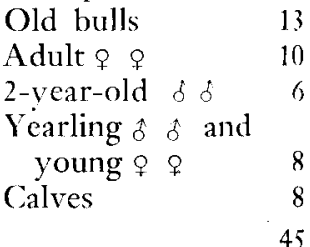

During this movement the bulls clean the velvet from their antlers by rubbing them on willows and other small bushes.

Beginning typically in October, the entire herd comes south through the main valley. The rut occurs in mid-Octobcr, and there is much fighting among the bulls. The migration lasts well into November. However, in 1949 the southward movement did not hegin until December. By January 1950 the main movement was towards the south, but on January 31 I saw a herd of from 3,000 to 4,000 animals moving to the north.

The following observations give some idea of the erratic nature of caribou movements:

In the fall of 1949 large numbers of caribou came out of Publatuk Creek from the east, and went up the main valley as far as Nachramkunga Creck, and on to the west. In December they moved in large numbers east through Inukpasukruk Creck and went over the divide into the Savioyok valley. They then apparently went on south and came back into the main valley via the Publatuk. Many re-entered the main valley just below Kalutak Creek. Some also came out along the Okoluk, and some over the high mountains near the fork called Kayak, at the confluence of the Kalutagiak and the John rivers. This general movement persisted until the end of A pril 1950, when the animals again moved northward through the main valley. The northward movement in 1950 persisted in the main valley until the end of Junc; after that no caribou were scen, except for a few stragglers, until late November. There were northward migrations farther to the west, however, through the vallev of Chandler Lake, from the middle of August through September. Large herds were seen moving cast, south of the Colville on the Arctic Slope. According to later information, it would seem that the main southward migration during the fall of 1950 took place through the Chandalar drainage. The first caribou coming south reached the divide between the two drainages on November 10 , and consisted mostly of males. About 2,000 animals, mostly females, were observed at Tulugak Lake on November 20. Another herd of more than 1,000 was seen on December 5. This southward migration continued into February 1951. During March caribou came north up the John River, and some also came north out of Inukpasukruk and Nachramkunga creeks. Not many caribou were seen in the main valley in early April. On April 23 about 500 animais, mostly females, came north from Inukpasukruk Creek. From late spring until late Scptember caribou were scarce. A few animals camc from Anivik (from aniruk, "come out") Creek during September and 
went north up the main valley. The main herd reached the divide, coming south, on 18 October 1951. At this time there was much fighting among the bulls.

Similar movements occur along the Killik River. From January through April there is usually a northward migration from the headwatcrs of the Noatak, to the west. In late July many animals come back into the mountains, seeking shelter from mosquitoes, according to the Fskimo. The main southward migration takes place in October, but some vcars it begins in September.

The Nunamiut state that the herd breaks into two main sections on the Arctic Slope, one of which goes cast, eventually reaching the Arctic Coast, and the other goes west. The western segment returns to the mountains, moves southward, and finally enters the main valley, retracing its route northward during late summer. I have not been able to verify this movement, but the Eskimo consider it to be the normal pattern of migration on the Arctic Slope.

I have not so far found any evidence to support the commonly-held view that the caribou are decreasing in this region. It is possible that this is the case, but neither local knowledge nor observations by qualified persons would support such a conclusion. The Nunamiut say there has been no decreasc; on the contrary, the old men say that caribou are much more numerous now than they were when they were young. This impression, of course, could readily result from a change in the migration routes.

A knowledge of the migration routes is essential for the proper management of these northern herds. If their migrations bring them into regions where they are subjected to heavy hunting pressure, measures must be taken to prevent their depletion. On the other hand, if they are relativcly restricted to the central Brooks Range, where the white man does not hunt, native hunting pressure is of no importance when the yearly increment is considered.

\begin{tabular}{|c|c|c|c|c|c|c|c|}
\hline $\operatorname{Sex}$ & Age & $\begin{array}{c}\text { Month } \\
\text { killed }\end{array}$ & Weight & Sex & Age & $\begin{array}{l}\text { Month } \\
\text { killed }\end{array}$ & Weight \\
\hline$\sigma^{7}$ & $6 \mathrm{mo}$. & Nov. & 65 & ף & $6 \mathrm{mo}$. & Nov. & 76 \\
\hline क) & 6 mo. & Nov. & 69 & 卉 & $6 \mathrm{mo}$. & Nov. & 83 \\
\hline$\sigma^{x}$ & $6 \mathrm{mo}$. & Nov. & 77 & $0^{+}$ & $2 \mathrm{yr}$ & April & 147 \\
\hline 8 & $6 \mathrm{mo}$. & Nov. & 97 & $0_{+}^{+}$ & 2 yr. & April & 148 \\
\hline $0^{7}$ & $6 \mathrm{mo}$. & Nov. & 117 & $\overbrace{+}^{+}$ & $3 \mathrm{yr}$. & Nov. & 150 \\
\hline$\sigma^{r}$ & $1 \mathrm{yr}$. & I)ec. & 140 & q & $4 \mathrm{yr}$. & Nov. & 170 \\
\hline$\sigma^{7}$ & $1 \mathrm{yr}$. & Dec. & 153 & ? & $4 \mathrm{yr}$. & Nov. & 210 \\
\hline$\sigma^{7}$ & $1 \mathrm{yr}$. & Nov. & 187 & $?$ & $5 \mathrm{yr}$ & Nov. & 180 \\
\hline$\sigma^{7}$ & $2 \mathrm{yr}$. & Feh. & 14.5 & ? & 7 to 8 yrs. & April & 204 \\
\hline$\sigma^{x}$ & $4 \mathrm{yr}$. & Feb. & 236 & 9 & Aged & April & 215 \\
\hline$\sigma^{\top}$ & $6 \mathrm{yr}$. & Feb. & 281 & & & & \\
\hline
\end{tabular}

Table IV. Live weights of 21 Brooks Range caribou (in pounds).

An effort was made to obtain the live weights of some caribou (Table IV), sincc, except those given by O. J. Murie (1935), few figures are available from the literature. All weights were taken when the old bulls were thin and without antlers. A big bull in September would weigh as nuch as 350 pounds.

It is anticipated that observations on aging will be published separately, when adequate material has been studied.

More controversial questions concern the caribou than any other mammal of this region. The most important of these involve reindecr-caribou and 
Wolf-caribou relationships. One of the most salient factors in connection with any attempt at caribou management is the influence of domestic reindeer on wild caribou stock. It is obvious, from past experience, that close herding is necessary if rcindeer are to be controlled. The coastal Eskimo do not seem temperamentally suited to close herding, with the result that great losses have occurred, when the unattended animals mingle with the wild caribou and migrate with them. Such losses are often attributcd to wolf predation, since this is an explanation which is readily accepted, and which absolves the herder of any blame. Wolves under some conditions no doubt do destroy reindeer. However, successful herders, such as Tom Brower of Point Barrow, who follow the close-herding method, consider damage by wolves to be negligible.

The admixture of inferior reindeer bloodlines with the native caribou is scrious. This has already occurred to a considerable degrec, and it is hoped that proper control will be exercised if the rcindeer industry is revived in Alaska. Far-notched animals have been killed in the Anaktuvuk Pass country, and white reindeer have been seen running with the caribou. The number of unrecognized reindeer passing through could be great. lantis (1950) has rcricwed the Alaskan reindeer situation.

There is no need here for more than a few passing remarks on the wolfcaribou relationship, since it has already been discussed in detail by A. Muric (1944). Onc must assume that predation has a regulatory effect of great value. In my opinion, any evidence of excessive predation automatically implies either an over-abundance of the prey species, or a disproportionate number of diseased or other physically inferior animals. Otherwise the predator is essentially in equilibrium with the species preyed upon. An example is the great modification of predator-prey relationships which occurs at the times of cyclic high population density of lemmings or other small rodents (Rausch, 1950a). Unfortunately, the principles pointed out by Errington (1946) are either poorly known or little considered. Hunting pressure is obviously not a satisfactory substitute for predation; the hunter, particularly the white man, attempts to kill the best animal possible, whilc under natural conditions the weak, diseased, or injured animals are those which will be eliminated. This concept is essentially substantiated by the work of such outstanding biologists as A. Muric (1944), Errington (1946), Leopold (1943; 1949), and Leopold, Sowls, and Spencer (1947). Unfortunately, the often ill-advised and uninformed "sportsman" still has an unjustified influcnce on game-management policies.

Diseased caribou have not been observed in this region. Larval cestodes (Taenia spp.) are common, but probably have no detrimental cffect and other parasites are few and unimportant. The natural movement of the herds prevents massive range contamination and precludes the building up of helminth infections to dangerous proportions. Infectious diseases can hardly survive in such a moving herd, since sick animals are left behind or are killed by wolves, thus preventing more than the minimum contact with healthy animals.

The heavy seasonal hunting of the Nunamiut results mainly in the killing of male animals. In the spring, hunting is begun as soon as the weather is 
favourable for preparing dried meat. By this time the bulk of the female animals has already gone out to the Arctic Slope. In the fall, when the herds are mixed, the bulls are sought because of their greater fat storage, and although a special effort is made to kill cows and calves for hides used in making certain garments, only a few animals are required.

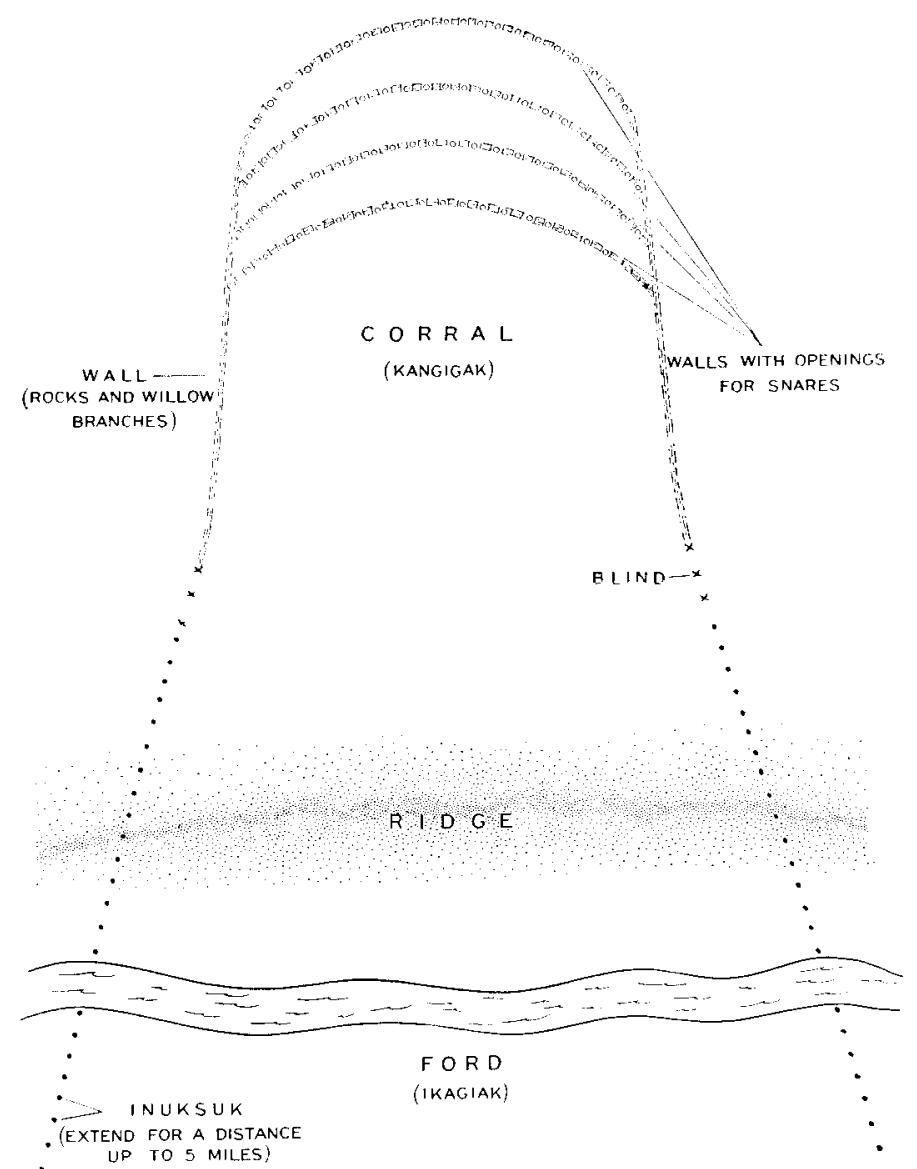

Fig. 15. Dingram of a corral (kangigak) formerly used by the Nunamiut for capturing caribou.

The Inland People formerly killed caribou with bows and arrows or with spears, and various methods were used to assist the hunt. One of the old methods, still employed, is to drive the caribou towards a favourable killing site by low piles of sod (imuksuk), placed cvery 50 feet or so in two converging rows. The animals fear these, and will not cross the rows under ordinary circumstances. Often a piecc of caribou hide is tied to a stake placed between the piles of sod, as the fluttering of the hide in the wind adds to the effectiveness of the barricr. Somctimes the caribou are made to enter a lake, where they are speared while swimming by the men in kayaks. Killing caribou in the water with the spear is called tutusiuvaktuat. Caribou were formerly snared, particularly in snares set in a corral (Fig. 15), The bottom of the loop of the 
snare was placed at a distance above the ground equal to the height of a man's knec plus the width of the hand with thumb extended, and the loop itself was large enough to enclose the antlers of a large bull. The corral, or kangigak, was constructed along a river where a low ridge prevented the caribou seeing it until too late for them to turn back, and was used year after year. It consisted of an enclosure of rocks and willow branches. The side walls were single, but the far end consisted of rows of alternate walls and openings in which the snares were set. Piles of sod diverged from the corral mouth for several miles, and the animals were driven by runners, called tovaksiroak. The people were careful to stay away from the front of the corral, or the caribou might detect the human scent. Once the caribou had forded the stream, they would not ordinarily return. Blinds were prepared at the mouth of the corral, and men waited in these while the drivers forced the animals over the ridge at high specd, into the mouth of the corral. The men then rushed from the blinds to close the entrance, shooting at the milling animals with the bow. Many were killed by arrows while those trying to escape through the openings of the back walls were snared.

The kangigak was last used about seventy-five years ago, when the parents of the men now living were young. The remains of an old corral are still visible near Tulugak Creek, just north of Tulugak Lake, and others arc found on the Killik River and near (handler lake, such as the one at Okominilaga. Stcfansson (1914, p. 385) gives a diagram of a corral similar to this, the details of which he got from a Tigiragmiut man.

The importance of the caribou to the Nunamiut is very evident. It is not surprising that three of their "moons" of the year are named for something to do with caribou. Thus, June is called Eriknivik ("fawning time"); Scptember, Amigaiksivik ("time velvet is lost from antlers"); and October is called Nuliakvik ("time of rut").

Through their long dependence upon the caribou, the Nunamiut have gained a thorough understanding of its habits. These men would be of great aid as observers in any intensive study of caribou, since there is probably no white man living who knows the animal as well.

The Nunamiut names for animals of the various ages are as follows:

Nogak-calf.

Angayukliakruk-yearling 8 .

Nukatagak-young 8 .

Nukatagakruk-3-year-old of.

Puknikruak-4-year-old $\delta$.

Priknik-bull, 5 years and older.

Kulavak-cow.

Five skulls, from near Tulugak Lake, have been deposited in the U.S. National Museum.

Ovibos moschatus ?moschatus (Zimmermann). Umikmmk (umik, "beard", -mituk, variant of -puk or -vuk, "big"). Muskox.

During the spring of 1951 Mr. John Krog, of the Arctic Health Research Center, picked up a badly-weathered muskox skull while making ornithological 
observations near Tulugak Creek. The Eskimo readily recognized the skull, but had no knowledge of the species occurring so far to the south. None had seen the animal alive in Alaska, but they had seen hides brought in from the east, and from time to time a skull or skeleton was found on the Arctic Slope. The oldest man of the group, Ahgook, told me of having shot muskoxen near the mouth of the Coppermine River when he was a young man. He was much impressed, apparently, by having shot a bull muskox in the head, only to have the bullet deflected by the massive horn formation.

This skull will be deposited in the U.S. National Museum by Mr. Krog, who kindly gave me permission to record his finding here.

Ovis dalli dalli (Nelson). Immaik (imnak, "cliff"). Dall sheep.

The Dall sheep is very common and widely distributed in the Brooks Range. Sheep do not play an important part in the econony of the Nunamiut, but they are taken from time to time when caribou are scarce.

The lambs are born in late May and early June, usually high on the mountain sides in a place safe from attack by wolves. The sheep remain high in the summer while vegetation is abundant, coming lower early in fallas early as the end of August. In the fall and winter they are of ten found around the willow-grown heads of small creeks.

The rut takes place in November, and the Nunamiut name for the full moon of November is Immait Nuliaviat ("time of the sheep rut"). The Nunamiut say that the rams pursue their own shadows in the bright moonlight at this time; this act is called by them tagaksiovik. After the breeding timc, the rams remain isolated from the ewes for the rest of the year, and are often seen in large flocks. Paneak told me of having seen a flock of 40 rams along the John River, but smaller groups are common. Flocks made up of ranis alone occur as late as the middle of October, but by this time some are already in company with the ewes and young animals.

I have never seen large flocks of sheep, but small flocks, with a maximum number of about 20 animals, are found throughout the mountains. According to the older Eskimo, there has been no decrease in shecp numbers. The people themselves kill few sheep, since they do not consider sheep hunting worth the time and ammunition. In view of their inaccessibility and failure to grow horns of unusual size, it is unlikely that these sheep will be sought by the trophy hunter.

There is some predation on sheep by wolves and wolverinc, but there is no evidence to suggest that it is ever important. Colden eagles are common, and no doubt kill a few lambs. A. Murie (194+) has given an enlightening account of shecp-wolf interrelationships.

In former days, the Nunamiut snared sheep on the mountain trails. The snare-line was attached to a buried rock, or, in some cases, particularly when there was snow, to the base of a small tree cut for the purpose, and the loop was supported by the smallest possible sticks. The distance of the bottom of the snare from the trail was equal to the height of a man's knee, and the loop was large enough to allow passage of the head of the largest ram. The 
Nunamiut stated that a big ram can break a stronger snare-line than can a moose.

There has been little opportunity to obtain sheep and only 6 animals havc been weighed (Table V). Some old rams probably weigh as much as 250 pounds and old barren females weigh more than the younger, breeding females. No diseased animals were seen, and no helminth parasites were found in the few animals examined. In the Brooks Range, any animals which are weakened by injury or disease will quickly be eliminated by the ever-present wolves.

\begin{tabular}{|c|c|c|c|}
\hline Sex & Age & Month killed & Weight \\
\hline$\sigma^{3}$ & $3 \mathrm{yr}$. & Oct. & 122 \\
\hline נ & $+\mathrm{yr}$ & Feb. & 110 \\
\hline अ & $10 \mathrm{yr}$ & Fet. & 15.3 \\
\hline o & 13 to 14 yrs. & Feb. & 190 \\
\hline O & lamb & Oct. & 51 \\
\hline$Q^{+}$ & adult & Oct. & 115 \\
\hline
\end{tabular}

Table V. Live weights of 6 Brook:; Range sheep (in pounds).

The Nunamiut have long known how to age sheep from horn growth, but they say that they cannot be certain of accuracy after the sheep are mature (9 years, according to them). Nevertheless, A. Murie (1944) reported aging rams several years older than this, and I have found it possible to age them accurately in this manner up to at least 15 years, if the horn is sawn lengthwise. According to the Fskimo, sheep are sometimes killed which are so old that the horn points are badly worn or broken, and the horn bases are very thick and roughened. Such animals must be well over 15 years old, since 1 have examined heads from shcep of this age without finding unusual conditions. Data on this will be presented later if adequate material can be obtained.

The Nunaniut names for sheep of various ages are as follows:

lvotuk-lamb.

Tamutailak-yearling ("has no teeth").

Kikiniktuligauruk-2- to 3-year-old is ("smallest black horn").

Kikiniktulikrak-4-year-old of ("last black colour").

Kamuyuknailak-5-year-old o ("hard to drag"), or older name Avalanarulik ("horns more spreading").

Nikilakralik-6-year-old o ("horn base size of young goose breast").

Kaumaktulik-7-year-old \& ("very light horn colour").

Kayutaksralik-8-year-old o ("big enough for dipper", referring to dipper formerly made of ram's horn).

Angutisukruk-mature ơ ("full grown").

Two skulls from Anaktuvuk Pass have been deposited in the U.S. National Museum. Additional material has been preserved for aging studies.

\section{RHFERENCES}

Anderson, R. M. 1924. "Range of the moose extending northward". Can. Field-Nat. Vol. 38, pp. 27-9.

Nat. Vol. 48, pp. 61-3.

1934. "Notes on the distribution of the hoary marmots". Can. Field.

1946. 'Catalogue of Canadian recent mammals'. Bull. Nat. Mus. Can. No, 102, Biol. Ser. No. 31, 238 pp.

Anderson, R. M., and A. L. Rand. 1945. "A new shrew from Arctic North America". Can. Field-Nat. Vol. 59, pp. 62-4. 
Bailey, A. M., and R. W. Hendec. 1926. "Notes on the mammals of northwestern Alaska". J. Mammal. Vol. 7, pp. 9-28.

Blair, W. F. 1939. "A swimming and diving meadow volc". J. Manmal. Vol. 20, p. 375.

Brooks, A. H. 1906. 'The geography and geology of Alaska'. U.S. Geol. Surv. Prof. Pap. $45,327 \mathrm{pp}$.

Degerbol, M., and P. Freuchen. 1935. 'Report of the mammals collected by the Fifth Thule Expedition to Arctic North America'. Rept. 5th Thule Exped. Copenhagen, 1921-4. Vol. 2, Nos. 4-5. $278 \mathrm{pp}$.

Dixon, J. S. 1933. "Red fox attacked by a golden eagle". J. Mammal. Vol. 14, p. 257. lirrington, P. L. 1946. "Predation and vertebrate populations". Quart. Rev. Biol. Vol. 21, pp. 144-77 and pp. 22I-45.

Gilmore, R. M. 1946. "Arctic mammalogy", in "A program of desirable scientific investigations in Arctic North America'. Arctic Inst. North America, Bull. 1, pp. 35-43.

Hall, E.. R. 1929. "Mammals collected by Charles D. Brower at Point Barrow, Alaska". Univ. Cal. Publ. Zool. Vol. 30, pp. 419-25.

Hall, E. R., and R. M. Gilmore. 1934. "Marmota caligata broweri, a new marmot from northern Alaska". Can. Field-Nat. Vol. 48, pp. 57-9.

Hatt, R. T. 1930. "The biology of the voles of New York" and "The relation of mammals to the Harvard forest". Roosevelt Wild Life Bull. Vol. 5, No.4, pp. 513-623 and Pp. 625-71.

Howell, A. H. 1936a. "A revision of the Ancrican arctic hares". I. Mammal. Vol. 17, pp. $315-37$.

19361. "Descriptions of three new red squirrels (Tantasciurus) from North America". Proc. Biol. Soc. Wash. Vol. 49, pp. 133-6.

Hultén, E. 1941-9. 'Flora of Alaska and Yukon'. Lunds Univers. Aarsskr., Pts. 1-9. lrving, I. "The birds of Anaktuvuk Pass, Alaska'. (Manuscript).

lantis, M. 1950. "The reindeer industry in Alaska". Arctic, Vol. 3, pp. 27-t4.

larsen, H., and F. Rainey. 1948. 'Ipiutak and the arctic whale hunting culture'. Anthro. Pap. Amer. Mus. Nat. Hist. Vol. 42, 276 pp. and plates.

Leopold, A. 1943. "Deer irruptions", in 'Wisconsin's deer problem'. Wis. Cons. Dept. Pub. No. 231, pp. 1-11.

1949. 'A sand County Almanac'. 226 pp. New York.

I.eopold, A., I.. K. Sowls, and D. L. Spencer. 1947. "A survey of over-populated deer ranges in the United States". J. Wildl. Man. Vol. 11, pp. 162-77.

Mc Taggart Cowan, l. 1949. "Rabies as a possible population control of arctic Canidae". J. Mammal. Vol. 30, pp. 396-8.

Murie, A. 1944. 'The wolves of Mount McKinley'. National Park Service, Fanna Ser. No. $5,238 \mathrm{pp}$.

Murie, O. J. 1935. 'Alaska-Yukon caribou'. North American Fauna, No. 54, 93 pp.

Quay, W. B. 1951. "Observations on manmials of the Seward Peninsula, Alaska". I. Mammal. Vol. 32, pp. 88-99.

Rand, A. L. 1945. 'Manmal investigations on the Canol Road, Yukon and Northwest Territories, 1944'. Bull. Nat. Mus. Canada, No. 99, Biol. Ser. No. 28, 52 pp.

Rausch, R. 1950a. "Observations on a cyclic decline of lemmings (Lemmutes) on the Arctic Coast of Alaska during the spring of 1949". Aritic, Vol. 3, pp. 166-77.

$1950 \mathrm{~b}$. "Notes on microtine rodents from the Brooks Range, Arctic Alaska". J. Wash. Acad. Sci. Vol. 40, pp. 133-6.

Schrader, F. C. 1904. 'A reconnaissance in northern Alaska'. U.S. Geol. Surr'. Prof. Pap. 20, $139 \mathrm{pp}$.

Seltzer, C. C. 1933. "The anthropometry of the Western and Copper Fskimos, based on data of Vilhjalmur Stefansson". Hwhan Biol. Vol. 5, pp. 313-70.

Solecki, R. S. 1950. "New data on the Inland Iskino of northern Alaska". J. Wash. Acad. Sci. Vol. 40, pp. 137-57.

Stefansson, V. 1913. 'My life with the liskimo'. 587 pp. New York.

1914. 'The Stefansson-Anderson Arctic Expedition of the American Museum: Preliminary Ethnological Report'. Antbro. Pap. Amer. Mus. Nat. Hist. Vol. 14, pp. 7-395.

Stoney, G. M. 1900. 'Naval explorations in Alaska'. 105 pp. Annapolis.

Troll, C. 1944. "Strukturböden, Solifluktion und Frostklinate der Frde". Cieol. Rundscb. Vol. 34, pp. 545-694. 